Check for updates

Cite this: New J. Chem., 2021, 45, 9598

Received 18th January 2021, Accepted 2nd April 2021

DOI: $10.1039 / d 1 n j 00293 g$

rsc.li/njc

\section{Synthesis and theoretical calculations of metal-antibiotic chelation with thiamphenicol: in vitro DNA and HSA binding, molecular docking, and cytotoxicity studies $\dagger$}

\author{
Abeer A. Sharfalddin, (D) a Abdul-Hamid Emwas, ${ }^{b}$ Mariusz Jaremko (D) ${ }^{c}$ and \\ Mostafa A. Hussien (D) *ad
}

\begin{abstract}
Thiamphenicol (TM) is an antimicrobial drug and a methyl-sulfonyl analogue of chloramphenicol. New metal complexes of TM with $\mathrm{Zn}(॥), \mathrm{Cu}(॥), \mathrm{Ni}(॥), \mathrm{Co}(॥)$ and $\mathrm{Fe}(॥)$ were synthesized and characterized using elemental analyses, infrared (IR) and proton nuclear magnetic resonance spectroscopy $\left({ }^{1} \mathrm{H}-\mathrm{NMR}\right)$, magnetic susceptibility, electron paramagnetic resonance (EPR) spectroscopy, and thermogravimetric analysis (TGA). The IR spectra revealed coordination of the deprotonated ligand to the metal through one oxygen and the nitrogen atom of the amide group. Moreover, EPR analysis of the Cu(I) solid sample indicated a distorted tetrahedral structure with a negligible exchange interaction between the $\mathrm{Cu}(I)$ ions. The UV-vis spectral results from the Co(॥) and Fe(॥) complexes showed a distorted tetrahedral geometric arrangement for both compounds. The DFT calculation approach was used to study the nature of the interaction between the metal ions and the ligand where the molecular stability and bond strengths were evaluated by Natural Bond Orbital (NBO) and quantum parameters. The biological activity of the metal complexes was investigated by several different bioassays. The DNA binding constant $K_{\mathrm{b}}$ showed an intercalation binding mode for both the free drug and the metal compounds. An in vitro protein (HSA) binding study showed binding with TM-Zn $K_{\mathrm{b}}=9.87 \times 10^{5} \mathrm{M}^{-1}$. The cytotoxic activity of each divalent complex was tested against two cell lines: (1) a human colon carcinoma (HCT-116) cell line and (2) a human breast carcinoma (MCF-7) tumor cell line and demonstrated anti-cancer cell activities. Molecular docking was utilized to explain the biological inhibition of the $\mathrm{Cu}(॥)$ and $\mathrm{Zn}(॥)$ complexes.
\end{abstract}

\section{Introduction}

Metal-based drugs derived from transition metals have been extensively studied for their biological activity. ${ }^{1}$ Enhancing their bioactivity is key to designing new and more effective medical drugs. Metal-based drug bioactivity can be increased by modulating the metal chelation, which in turn decreases their toxicity and enhances their lipophilicity, absorbance,

\footnotetext{
${ }^{a}$ Department of Chemistry, Faculty of Science, King Abdulaziz University, P. O. Box 80203, Jeddah 21589, Saudi Arabia

${ }^{b}$ King Abdullah University of Science and Technology (KAUST), Thuwal, 23955-6900, Saudi Arabia

${ }^{c}$ King Abdullah University of Science and Technology (KAUST), Biological and Environmental Science and Engineering (BESE), Thuwal, 23955-6900, Saudi Arabia

${ }^{d}$ Department of Chemistry, Faculty of Science, Port Said University, Port Said, 42521, Egypt

$\dagger$ Electronic supplementary information (ESI) available. See DOI: 10.1039/ d1nj00293g
}

and stability. ${ }^{2}$ Some transition metals are essential components of biological systems, playing diverse roles including as cofactors in the enzyme oxidation process, controlling the geometry of the enzymic active sites, and activating enzymatic reactions. ${ }^{3}$ Moreover, they are present in vitamins such as $\mathrm{Co}(\mathrm{II})$ in $\mathrm{B}_{12}$. Copper is essential for nervous system development and it exists in many enzymes and proteins with a range of functions such as in energy metabolism. ${ }^{4}$ Zinc is the most abundant transition metal in the human body playing several important roles including in immunity and metabolism, and is crucial for the function of more than 300 enzymes. $^{3,5}$

Thiamphenicol (TM), also known as dextrosulphenidol, ${ }^{6}$ is an antimicrobial drug with broad antibiotic activity. It is an analogue of chloramphenicol by $\mathrm{NO}_{2}$ substitution with methyl sulfinyl, and is 2.5 to 5 times more potent than chloramphenicol. ${ }^{7}$ The chemical structure of TM has three donor atoms that could coordinate to a metal ion: the primary alcohol, the secondary alcohol, and the amide group. 
However, until now, the reaction of TM with biological metals or other inorganic metals has not been well investigated.

Attempting to improve the efficiency of the free drug, five new metal complexes were synthesized in ethanol solution and characterized by analytical, spectroscopic, and thermal techniques. DNA helix is a biomolecule that represents a major target in the development strategies of the drugs designed. ${ }^{8}$ Among many other transporting proteins human serum albumin (HSA) is the main carrier of ions and molecules in the blood plasma. The interaction of a biological target such as DNA or specific protein to drugs could change their structure or inhibit their activity. For this purpose, we evaluated the binding affinity of the metal complexes to a pharmacological target using spectroscopic experiments with CT-DNA and human serum albumin (HSA). The cytotoxic activity of the prepared compounds was tested theoretically via molecular docking against two proteins, 4FM9 and $1 \mathrm{H} 7 \mathrm{~K}$. Finally, we tested the complexes' in vitro activity against human colon carcinoma (HCT-116) and human breast carcinoma (MCF-7) tumor cell lines.

\section{Experimental methods}

\subsection{Chemicals and reagents}

Thiamphenicol of 99\% purity was purchased from Aldrich. All chemicals used in this study, including the metal(II) salts and solvents, were of analytical reagent grade, commercially available from $\mathrm{BDH}$ and used without further purification.

\subsection{Synthesis of the metal(II) complexes}

A refluxing method was used to prepare the divalent metal complexes at a $1: 2$ (M:TM) molar ratio. Appropriate amounts of $\mathrm{CuCl}_{2}, \mathrm{CoCl}_{2}, \mathrm{ZnCl}_{2}, \mathrm{NiCl}_{2}$, or $\mathrm{FeCl}_{2}$ were dissolved in ethanol and added to $2 \mathrm{mmol}$ of TM $(0.712 \mathrm{~g})$ ligand solution in ethanol, $\mathrm{pH}=8.9$ adjusted by $\mathrm{KOH}$. The mixture was incubated on a hotplate for 2-3 h. Solid precipitates were formed after leaving the mixtures overnight till the volumes reduced by half. This was followed by filtering and washing with a few drops of ethanol and diethyl ether. Finally, the complexes were dried in a vacuum desiccator over anhydrous $\mathrm{CaCl}_{2}$ in preparation for characterization. There were many attempts to get single crystals from the metal complexes using the diffusion method with DMS and chloroform or ethanol and benzene but all failed.

\subsection{Physicochemical measurements}

Infrared spectra of the TM ligand and its complexes were recorded on a Bruker infrared spectrophotometer in the range of 400-4000 $\mathrm{cm}^{-1}$. The molar conductance and the electronic spectra of $10^{-3} \mathrm{M}$ solutions of the metal complexes in DMF solvent were measured on a $\mathrm{HACH}$ conductivity meter and Shimadzu UV/vis spectrometer in the range of 200-800 $\mathrm{nm}$. All the measurements were taken at room temperature for freshly prepared solutions. Microanalytical analyses (\% carbon, $\%$ hydrogen and \% nitrogen) were carried out on a Vario EL Fab. CHNS. The content of metal ions was calculated gravimetrically as metal oxides. ${ }^{1} \mathrm{H}$-NMR spectra were recorded in DMSO d ${ }^{6}$ solutions on a Bruker $850 \mathrm{MHz}$ spectrometer using TMS as the internal standard. The mass susceptibility of the metal complexes was measured at room temperature using Gouy's method using a magnetic susceptibility balance from Johnson Matthey (Sherwood model). EPR spectra in the solid state were acquired using a continuous wave Bruker EMX PLUS spectrometer operating at an $\mathrm{X}$ band frequency $(9.5 \mathrm{GHz})$. Thermogravimetric analysis TG-DTG experiments were conducted using a Mettler Toledo STARe thermal analysis system with the STARe software. All experiments were performed using a single loose top loading platinum sample pan under air at a flow rate of $30 \mathrm{ml} \mathrm{min} \operatorname{mon}^{-1}$ and $10{ }^{\circ} \mathrm{C} \min ^{-1}$ heating rate for the temperature range $25-800{ }^{\circ} \mathrm{C}$.

\subsection{Theoretical aspects}

The Gaussian 09 software package ${ }^{9}$ was used for the optimization calculations of the free ligand and its metal complexes. The DFT method using the hybrid density functional B3LYP was used with the $6-311 G(d, p)$ for the ligand and the LANL2DZ basis set was used for the metal ions for the metal complexes in the gas phase. Vibrational frequencies were calculated to ensure that the optimized geometry corresponds to a true energy minimum. The calculated harmonic frequencies were scaled by a factor of 0.966 and 0.961 for 6-31G(d,p) and LANL2DZ basis set, respectively. ${ }^{10}$ GaussView software ${ }^{11}$ was used to visualize the output files and to prepare the figures showing the molecular orbitals (MOs). HOMO and LUMO energies were obtained and used to calculate essential quantum parameters using the following equations: energy gap ( $\left.E_{\text {gap }}=E_{\mathrm{LUMO}}-E_{\mathrm{HOMO}}\right)$, absolute electronegativities $\left(\chi=-E_{\mathrm{HOMO}}+E_{\mathrm{LUMO}} / 2\right)$, absolute hardness $(\eta=$ $\left.E_{\mathrm{LUMO}}-E_{\mathrm{HOMO}} / 2\right)$, chemical potentials $(\mu=-\chi)$, global softness $(S=1 / 2 \eta)$, and global electrophilicity $\left(\omega=\pi^{2} / 2 \eta\right) \cdot{ }^{12,13}$ MEP maps were projected by applying the B3LYP/LANL2DZ level within DFT.

\subsection{Biological application}

2.5.1 DNA-binding experiments. All DNA-binding experiments were performed at room temperature. First, a fresh CT-DNA solution was prepared in buffer solution with a UV absorbance ratio of 1.8 at 260 and $280 \mathrm{~nm}$, indicating that the DNA was sufficiently free of proteins. ${ }^{14,15}$ The stock solution was maintained at $5{ }^{\circ} \mathrm{C}$ and used within one week. A fixed concentration of $4 \mu \mathrm{M}$ was prepared in a minimum amount of DMSO to maintain the compounds' solubility during the experiment in buffer and used in spectroscopic investigations with varying CT-DNA concentrations in the range 1.57-5.15 $\mu \mathrm{M}$. The mixture was allowed to incubate for one hour before recording the absorbance. The binding constant $K_{\mathrm{b}}$ was computed with the Benesi-Hildebrand equation, which is defined as ${ }^{16,17}$

$$
[\mathrm{DNA}] /\left(\varepsilon_{\mathrm{a}}-\varepsilon_{\mathrm{f}}\right)=[\mathrm{DNA}] /\left(\varepsilon_{\mathrm{b}}-\varepsilon_{\mathrm{f}}\right)+1 / K_{\mathrm{b}}\left(\varepsilon_{\mathrm{a}}-\varepsilon_{\mathrm{f}}\right) .
$$

Here, $[\mathrm{DNA}]=$ the concentration of CT-DNA in base pairs. $\varepsilon_{\mathrm{a}}=$ the extinction coefficient observed for $A_{\text {obs }} /[$ compound $]$ at the given DNA concentration. $\varepsilon_{\mathrm{f}}=$ the extinction coefficient of the free compound in solution. $\varepsilon_{\mathrm{b}}=$ the extinction coefficient of the compound when binding to DNA. $K_{\mathrm{b}}=$ the ratio 
of the slope to the intercept of the plot $[\mathrm{DNA}] /\left(\varepsilon_{\mathrm{a}}-\varepsilon_{\mathrm{f}}\right)$ versus [DNA].

The slope-to-intercept ratio was collected by plotting [DNA]/ $\left(\varepsilon_{\mathrm{b}}-\varepsilon_{\mathrm{f}}\right)$ versus [DNA], which is the $K_{\mathrm{b}}$ value. The standard Gibbs free energy $(\Delta G)$ for DNA binding was evaluated from the following relationship: $\Delta G_{\mathrm{b}}^{\neq}=-R T \ln K_{\mathrm{b}},{ }^{18}$ where $R=$ $8.314 \mathrm{~J} \mathrm{~K}^{-1} \mathrm{~mol}^{-1}$ and $T=298 \mathrm{~K}$.

2.5.2 In vitro HSA binding study. A stock solution of human serum albumin (HSA (A1887; globulin and fatty acid free)) was prepared in Tris-HCl buffer at $\mathrm{pH}$ 7.2. Spectrometry method was used to determine the protein concentration with the extinction coefficient $35219 \mathrm{M}^{-1} \mathrm{~cm}^{-1}$ at $280 \mathrm{~nm}$ using quartz cuvettes of $1 \mathrm{~cm}$ path-length. Complex solutions with $1.1 \times 10^{-3} \mathrm{M}^{-1}$ were prepared in DMS. The HSA concentration was kept constant during the titration experiment while the complex concentration was varied in the range $1.57 \times 10^{-5}$ to $5.15 \times 10^{-5} \mu \mathrm{M}$. The intrinsic binding constants $\left(k_{\mathrm{b}}\right)$ of the metal complexes with HSA were calculated using the following equation:

$$
\frac{A_{0}}{A-A_{0}}=\frac{\varepsilon_{\mathrm{HSA}}}{\varepsilon_{\mathrm{b}}}+\frac{\varepsilon_{\mathrm{HSA}}}{\varepsilon_{\mathrm{b}} K} \times \frac{1}{C_{\text {complex }}}
$$

where $A_{0}$ and $A$ are the absorbance of HSA at $280 \mathrm{~nm}$ in the absence and presence of the complex, respectively. $\varepsilon_{\mathrm{HSA}}$ and $\varepsilon_{\mathrm{b}}$ are the molar extinction coefficient of HSA and the HSA bound complex. The relation of $1 / A-A_{0} v s .1 / C_{\text {complex }}$ is linear and $K_{\mathrm{b}}$ could be estimated from the ratio of the intercept to the slope.

2.5.3 Molecular docking. Molecular docking modeling was performed using the MOE program. The crystal structures of the target proteins for breast and colon cancer receptors were downloaded from the Protein Data Bank (PDB codes $1 \mathrm{H} 7 \mathrm{~K}$ and 4FM9, respectively). We used the docking process described in previous work. ${ }^{12}$ After finding potential binding sites on the protein using Site Finder, the bound water, ligands and cofactors were removed from the protein. Then, the metal complexes were minimized to the lowest energy using the MMFF94 force field. The general docking scenario was run on the rigid receptor atoms, and the ligand and metal complexes were placed in the site with the triangle matcher method. London dG was utilized as a scoring function and the GBVI/ WSA dG methods for rescoring. The five best poses were ranked by the binding free energy $(S)$ and the hydrogen bonds between the compounds and amino acids in the protein whose lengths did not exceed 3.5 A. Moreover, RMSD and RMSD-refine fields were used to compare the results pose-with-pose in the co-crystal ligand position and before and after amendment, respectively.

2.5.4 Anti-cancer activities. The cytotoxicity of the metal-TM complexes was evaluated using the MTT protocol ${ }^{19}$ with human colon carcinoma (HCT-116) cells and human breast cancer (MCF-7) cells. The cell cultures were propagated as reported. ${ }^{20}$ Samples in $0.1 \%$ DMSO were used to prepare different concentrations in fresh medium (serial two-fold dilutions) and were then incubated at $37{ }^{\circ} \mathrm{C}$ for $24 \mathrm{~h}$. The test was performed three times for each sample concentration. Control cells were incubated without a test sample and with or without DMSO.
After $24 \mathrm{~h}$ incubation, the medium was aspirated and a 1\% solution of crystal violet was added to each well and left for at least 30 minutes. The excess stain was removed from the plates and rinsed using tap water before measuring the absorbance of the plates at $490 \mathrm{~nm}$. To calculate the percentage of viable cells, the mean of three measured values of the optical density of the well treated with a metal-TM complex (ODt) was divided by the mean of the optical density of untreated cells (ODc), i.e., $[(\mathrm{ODt} / \mathrm{ODc})] \times$ 100. Graphpad Prism software (San Diego, CA, USA) was used to plot the relationship between the percentage of surviving cells and the drug concentration to obtain survival curves for each cancer cell line, from which the $\mathrm{IC}_{50}$ value was estimated.

\section{Results and discussion}

\subsection{Analytical and physical data}

The new metal complexes were prepared by reacting the TM ligand with transition metal salts in ethanoic solution with the $\mathrm{pH}$ adjusted to 8.9 with $\mathrm{KOH}$, Scheme 1. The prepared metal complexes were tested using elemental analysis, infrared spectroscopy (IR), ${ }^{1} \mathrm{H}-\mathrm{NMR}$, UV-vis, conductometric measurements and magnetic susceptibility measurements, as well as density functional theory (DFT) analysis.

The physical properties of TM and the metal complexes and elemental analysis are listed in Table 1. The colored solid TM complexes were stable in air, insoluble in some polar solvents, such as $\mathrm{H}_{2} \mathrm{O}$ and ethanol solvents, and readily soluble in DMSO and DMF. Moreover, they had low conductance values in DMF, $1 \times 10^{-3} \mathrm{M}$, indicating that the complexes are neutral complexes. $^{21}$ TM has two sites to coordinate to the metal ion as a bidentate ligand: the two hydroxyl groups or the oxygen and nitrogen atoms of the amide group. ${ }^{22}$ The calculated elemental values were in good agreement with the experimental results.

\subsection{Infrared (IR) spectra}

The IR spectra of TM and the Cu(II), Co(II), Fe(II), Ni(II) and Zn(II) complexes are shown in Fig. S1 (ESI $\dagger$ ) while Table 2 illustrates the main bands and their assignments for the free TM ligand and its metal complexes. Experimentally, the bands observed between 3490 and $3450 \mathrm{~cm}^{-1}$ were assigned to stretching $\nu(\mathrm{OH})$ and $\nu(\mathrm{NH})$ in the free ligand spectrum. Upon complexation, both $\nu(\mathrm{OH})$ and $\nu(\mathrm{NH})$ frequency shifted to a higher frequency.

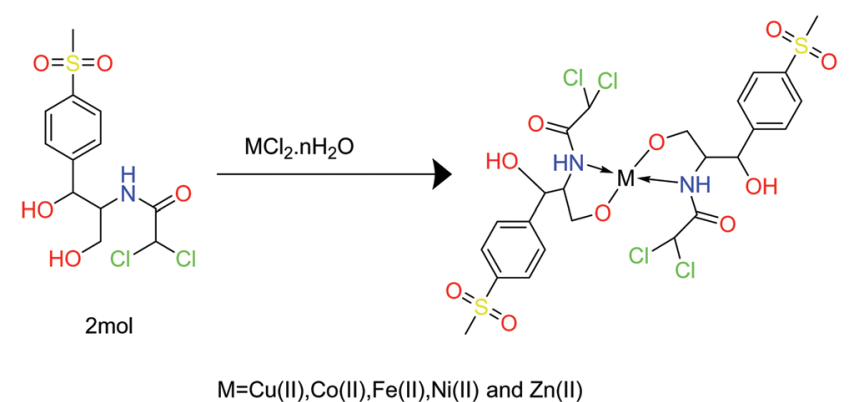

Scheme 1 Chemical reactions for the preparation of the metal complexes. 
Table 1 Analytical and physical data of the free TM ligand and the metal-TM complexes

\begin{tabular}{|c|c|c|c|c|c|c|c|c|c|}
\hline \multirow[b]{2}{*}{ Metal complex } & \multirow{2}{*}{$\begin{array}{l}\text { M. wt., } \\
\text { g mol }\end{array}$} & \multirow[b]{2}{*}{ Color } & \multicolumn{5}{|c|}{ Elemental analysis \% calc. (\% found) } & \multirow{2}{*}{$\begin{array}{l}\Lambda m, \\
\Omega \mathrm{cm}^{2} \mathrm{~mol}^{-1}\end{array}$} & \multirow{2}{*}{$\begin{array}{l}\text { Melting } \\
\text { point, }{ }^{\circ} \mathrm{C}\end{array}$} \\
\hline & & & $\mathrm{C}$ & $\mathrm{N}$ & $\mathrm{S}$ & $\mathrm{H}$ & M & & \\
\hline TM & 356.22 & White & $40.50(40.46)$ & $3.90(3.93)$ & $8.90(8.95)$ & $4.80(4.78)$ & - & $<1$ & 165 \\
\hline $\mathrm{Cu}(\mathrm{TM})_{2}$ & 771 & Dark gold & $37.34(37.33)$ & $3.63(3.69)$ & $8.31(8.35)$ & $3.40(3.42)$ & $8.23(8.26)$ & 3.13 & 212 \\
\hline $\mathrm{Co}(\mathrm{TM})_{2}$ & 767.3 & Dim gray & $37.57(37.53)$ & $3.60(3.59)$ & $8.36(8.36)$ & $3.40(3.38)$ & $7.70(7.71)$ & 3.13 & 326 \\
\hline $\mathrm{Ni}(\mathrm{TM})_{2}$ & 767.1 & Pale green & $37.58(37.60)$ & $3.60(3.59)$ & $8.36(3.36)$ & $3.41(3.39)$ & $7.62(7.70)$ & 20.31 & 227 \\
\hline $\mathrm{Fe}(\mathrm{TM})_{2}$ & 764.2 & Dark red & $37.72(37.70)$ & $3.64(3.61)$ & $8.39(8.35)$ & $3.42(3.39)$ & $7.28(7.30)$ & 1.56 & 207 \\
\hline $\mathrm{Zn}(\mathrm{TM})_{2}$ & 773.8 & White & $37.25(37.26)$ & $3.60(3.62)$ & $8.45(8.42)$ & $3.40(3.41)$ & $8.45(8.44)$ & 1.56 & 259 \\
\hline
\end{tabular}

Table 2 Analysis of the main IR peaks for the experimental (theoretical) spectral bands and their assignments for the free TM ligand and its complexes

\begin{tabular}{|c|c|c|c|c|c|c|}
\hline $\mathrm{Cu}-\mathrm{TM}$ & $1690(1692)$ & $1515(1490)$ & 1084 (1093) & 1141 (1137) & $504(510)$ & 406 (396) \\
\hline $\mathrm{Ni}-\mathrm{TM}$ & 1689 (1691) & 1515 (1488) & $1084(1093)$ & 1141 (1137) & 507 (511) & 406 (397) \\
\hline $\mathrm{Fe}-\mathrm{TM}$ & 1689 (1691) & 1515 (1490) & 1084 (1093) & 1140 (1136) & $506(511)$ & 405 (396) \\
\hline $\mathrm{Zn}-\mathrm{TM}$ & 1689 (1691) & $1514(1500)$ & 1084 (1093) & $1142(1137)$ & $506(511)$ & $406(396)$ \\
\hline
\end{tabular}

Moreover, in the metal-TM complexes, $\nu(\mathrm{C}=\mathrm{O})$ stretching was still present at $1690 \mathrm{~cm}^{-1}$, which revealed that it was not involved in metal coordination. The $\mathrm{NH}$ bending appearing at $1515 \mathrm{~cm}^{-1}$ showed a small shift with increasing intensity, which indicated the association of $\mathrm{NH}$ in the metal coordination. The free ligand had two strong bands in the $\mathrm{C}-\mathrm{O}$ region, namely at $1186-1146 \mathrm{~cm}^{-1}$, which were assigned to the secondary and primary alcohol, respectively. ${ }^{7}$ The clear blue shift upon complexation for the $\mathrm{CH}-\mathrm{OH}$ peak proved that the ligand coordinates to the metal through the hydroxyl group. The new bands in the IR spectra for all the metal-TM complexes in the $500-420 \mathrm{~cm}^{-1}$ range were assigned to the $\nu \mathrm{M}-\mathrm{O}$ and $\nu \mathbf{M}-\mathbf{N}$ bands. ${ }^{23,24}$

The theoretical spectra calculated with B3LYP/6-311G(d,p) for the ligand and using the LANL2DZ basis set for the metal complexes strongly correlated with the experimental bands as presented in Table 2 and the comparison spectra are shown in the ESI. $\dagger$

\subsection{Proton nuclear magnetic resonance ( $\left.{ }^{1} \mathrm{H}-\mathrm{NMR}\right)$}

The spectral data of the free TM ligand and the $\mathrm{Zn}$ (II) complex were recorded in $\mathrm{d}_{6}$ dimethyl sulfoxide solvent and are presented in Fig. 1. The signals at 4.99-5.95 ppm represent the $\mathrm{OH}$ group in the free ligand ${ }^{7}$ for the primary and secondary alcohol, respectively. The primary alcohol at $4.99 \mathrm{ppm}$ was affected via the metal magnet in the spectrum of $\mathrm{Zn}(\mathrm{TM})_{2}$ and vanished. This revealed that the coordination was through the oxygen atom of the $\mathrm{OH}$ groups. In contrast, the secondary $\mathrm{OH}$ was maintained at $5.95 \mathrm{ppm}$. Additionally, the $\mathrm{NH}$ signal in the ${ }^{1} \mathrm{H}$-NMR spectrum of the ligand at $8.31 \mathrm{ppm}$ appeared at the same position with a slight shift and showed a change in multiplicity from a doublet to a singlet. The characteristic signals for the free TM ligand and the metal complexes are presented in Table 3.

\subsection{Magnetic susceptibility and the electronic spectra}

Electronic absorption spectroscopy was performed in DMSO solution at room temperature for TM as a free ligand and the colored divalent metal complexes; the $\mathrm{Ni}(\mathrm{II}), \mathrm{Co}(\mathrm{II}), \mathrm{Cu}(\mathrm{II})$ and $\mathrm{Fe}(\mathrm{II})$ complexes are shown in Fig. 2. The essential maximum peaks for the ligand at 266 and $339 \mathrm{~nm}$ were due to the transitions $\mathrm{n} \rightarrow \pi^{*}$ and $\pi \rightarrow \pi^{*}$, respectively, which were absorbed within the amide group ${ }^{7}$ and shifted to high or low wavelengths after complexation.

The Ni-TM compound presented two bands, at 14.286 and $12.820 \mathrm{~cm}^{-1}$, which were assigned to the transitions ${ }^{3} \mathrm{~T}_{2}(\mathrm{~F}) \rightarrow{ }^{3} \mathrm{~A}_{2}$ and ${ }^{3} \mathrm{~T}_{1}(\mathrm{~F}) \rightarrow{ }^{3} \mathrm{~T}_{1}(\mathrm{P})$, respectively. These bands demonstrate an intermediate structure between a square planar and a tetrahedral geometry. ${ }^{25,26}$ Moreover, the effective magnetic moment $\left(\mu_{\text {eff }}\right)$ of $1.29 \mathrm{BM}$ for the Ni-TM compound verified this result. ${ }^{27}$ The $\mathrm{Fe}(\mathrm{II})$ complex had a tetrahedral structure and paramagnetic nature $\left(\mu_{\mathrm{eff}}=4.63 \mathrm{BM}\right)$, which usually indicates electronic transitions in the near-infrared region. ${ }^{28,29}$ We attributed the complex color to an electron transition located by an obscured band that overlapped with $390 \mathrm{~nm}$, which was assigned to charge transfer transitions from the metal to empty orbitals of the ligand, causing the intensely colored complex. ${ }^{30}$ The Co-TM compound presented two bands at 550-667 nm corresponding to ${ }^{4} \mathrm{~A}_{2} \rightarrow{ }^{4} \mathrm{~T}_{1}(\mathrm{P})$ and ${ }^{4} \mathrm{~A}_{2} \rightarrow{ }^{4} \mathrm{~T}_{1}(\mathrm{~F})$. Although the electronic spectra of tetrahedral $\mathrm{Co}(\mathrm{II})$ always show three spin-allowed transitions, the transition of ${ }^{4} \mathrm{~A}_{2} \rightarrow{ }^{4} \mathrm{~T}_{1}(\mathrm{~F})$ often dominates. ${ }^{27}$ Moreover, the obtained magnetic moment value for $\mathrm{Co}(\mathrm{II})$ was in the reported range of the tetrahedral geometry. ${ }^{27}$ The $\mathrm{Cu}(\mathrm{II})$ complex displayed one prominent broad band at $10917 \mathrm{~cm}^{-1}$, which we assigned to the $\mathrm{d} \rightarrow \mathrm{d}$ transition. ${ }^{31}$ The $\mathrm{Zn}$ (II) complex was diamagnetic in nature and has a tetrahedral structure. Table 4 summarizes the main electronic bands and the assignments for the $\mathrm{Ni}(\mathrm{II})$ and $\mathrm{Co}(\mathrm{II})$ metal complexes.

\subsection{Electron paramagnetic resonance analysis (EPR)}

Electron spin resonance (ESR), also known as electron paramagnetic resonance (EPR), is a powerful analytical tool that selectively detects species with unpaired electrons such as paramagnetic transition metal complexes like copper and iron 
TM

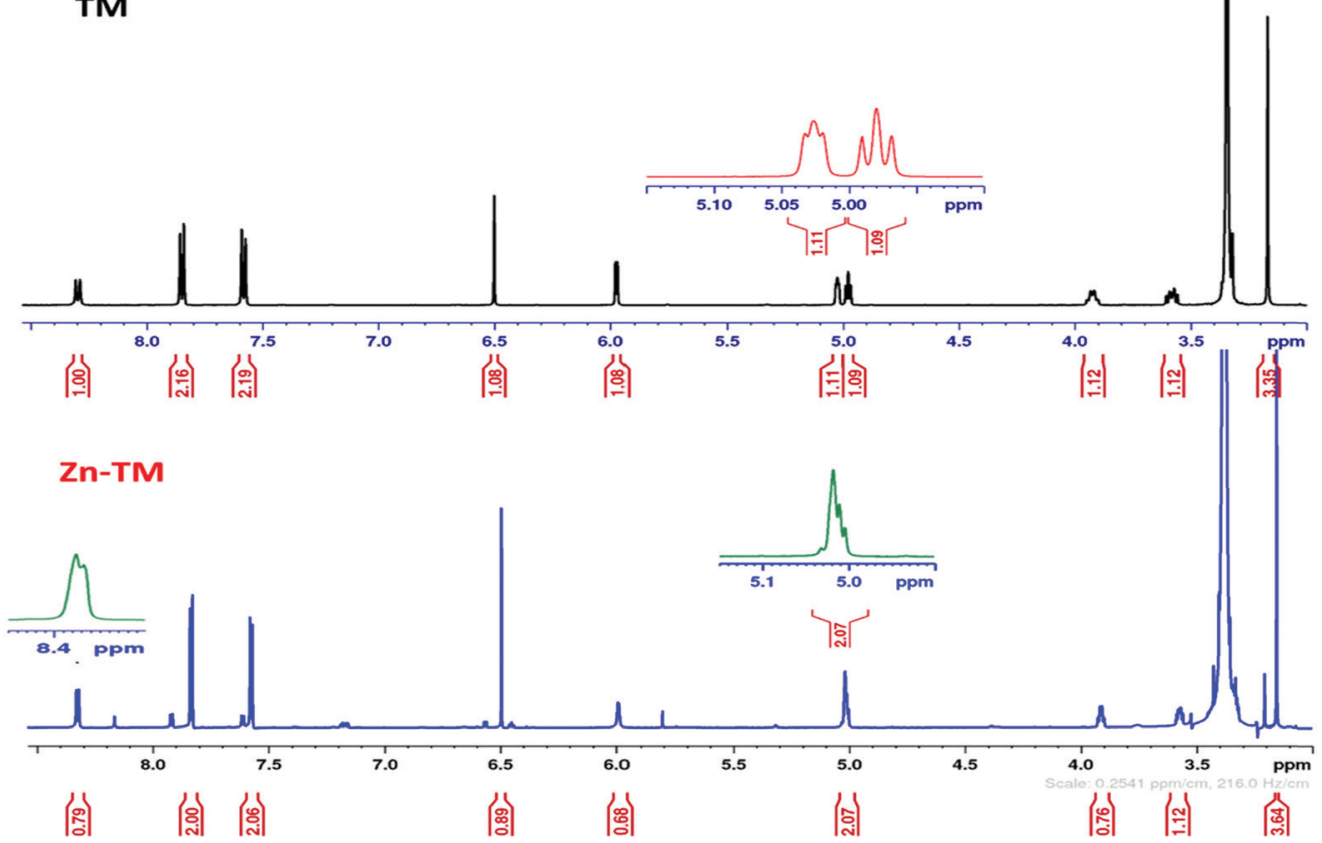

Fig. 1 The ${ }^{1} \mathrm{H}-\mathrm{NMR}$ spectra of $\mathrm{Zn}-\mathrm{TM}$ and the free ligand (TM).

Table 3 Chemical shift of the free TM ligand and Zn(॥) complex

\begin{tabular}{|c|c|c|}
\hline Assignments & $\delta(\mathrm{ppm})$ free $\mathrm{TM}$ & $\delta(\mathrm{ppm}) \mathrm{Zn}-\mathrm{TM}$ \\
\hline$-\mathrm{CH}_{3}$ & 3.16 & 3.16 \\
\hline$-\underline{\mathrm{C}}_{2}-\mathrm{OH}$ & 3.6 & 3.56 \\
\hline $\mathrm{C} H-\mathrm{N}$ & 3.94 & 3.93 \\
\hline$-\mathrm{CH}_{2}-\underline{\mathrm{OH}}$ & 4.99 & - \\
\hline $\mathrm{C} \mathrm{H}-\mathrm{OH}$ & 4.97 & 5.1 \\
\hline $\mathrm{CH}-\underline{\mathrm{OH}}$ & 5.97 & 5.97 \\
\hline $\mathrm{COCHCl}_{2}$ & 6.5 & 6.5 \\
\hline $\mathrm{Ar}$ & $7.85-7.58$ & $7.85-7.58$ \\
\hline $\mathrm{NH}$ & 8.31 & 8.32 \\
\hline
\end{tabular}

complexes $^{32,33}$ and organic free radicals. ${ }^{34-37}$ In addition to structural information, EPR spectra provide important information on the atoms that coordinate with the transition metal. ${ }^{38-40}$ The solid sample spectrum of the Cu-TM compound obtained in $\mathrm{X}$-band EPR spectroscopy at room temperature is shown in Fig. 3. Based on the $g$-values, it showed a characteristic axial symmetry with $g_{\|}$(2.32) and $g_{\perp}(2.07)>2.0023$ and is a distorted tetrahedron. ${ }^{41}$ Therefore, the ground state will be $\mathrm{d}_{x^{2}-y^{2}}$ and has a highest half-occupied orbital that repels the ligand in the equatorial plane. ${ }^{42,43}$ The $g_{\text {av }}$ value, calculated by the equation $g_{\text {av }}=\left(g_{\|}+2 g_{\perp}\right) / 3,{ }^{44,45}$ was 2.14 and indicates a covalent environment around the $\mathrm{Cu}$ (II) metal ion. ${ }^{46}$ To study the exchange interaction between the $\mathrm{Cu}$ (II) ions in a powder solid sample, the $G$ value was computed using ${ }^{42,47}$

$$
G=\left(g_{\|}-g_{\mathrm{e}}\right) /\left(g_{\perp}-g_{\mathrm{e}}\right)
$$

According to the reported literature, if $G$ is between 3 and 5, then the magnetic environment in the cell is equivalent; if $5<G<3$, then the exchange coupling in the unit cell is not

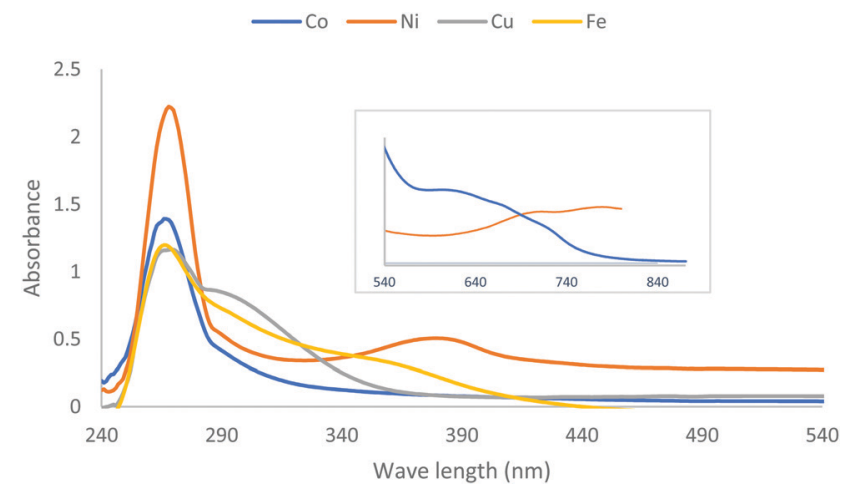

Fig. 2 UV spectra for the TM and metal complexes.

equivalent. ${ }^{48}$ The calculated value of $G=4.27$ reflects that the exchange interaction is negligible between the $\mathrm{Cu}(\mathrm{II})$ ions. ${ }^{44,48}$

\subsection{Thermal analysis (TGA)}

The crystal water content in the complexes and the mass loss percentage for the transition metal coordination complexes were studied by a thermal technique in order to analyze their stability. All the metal-TM complexes had a similar decomposition step over the temperature range $70-500{ }^{\circ} \mathrm{C}$, with the exception of the $\mathrm{Co}$ (II) and $\mathrm{Zn}$ (II) compounds. In atmospheric air, $\mathrm{Cu}-\mathrm{TM}, \mathrm{Fe}-\mathrm{TM}$ and Ni-TM were stable up to $\sim 119{ }^{\circ} \mathrm{C}$ and the decomposition occurred in three stages. The first decomposition stage began with the loss of $\mathrm{HCl}$ in the range 150-200 ${ }^{\circ} \mathrm{C}$. The formed compounds underwent further decomposition from 207 to $280{ }^{\circ} \mathrm{C}$ with a mass loss percentage 
Table 4 Summary of the main magnetic and spectral parameters and the assignments for the TM ligand, and Ni(॥) and Co(॥) complexes

\begin{tabular}{lllllll}
\hline & \multicolumn{2}{l}{ Bands $\mathrm{nm}\left(\mathrm{cm}^{-1}\right)$} & & & \\
\cline { 2 - 5 } Complex & $\mathrm{V}$ & $\mathrm{V} 3$ & $\mathrm{~V} 2$ & Assignment & Magnetic moment (B.M.) \\
\hline $\mathrm{Co}(\mathrm{TM})_{2}$ & $400(25.000)$ & $558(18000)$ & $631(16000)$ & & ${ }^{4} \mathrm{~A}_{2} \rightarrow{ }^{4} \mathrm{~T}_{1}(\mathrm{P}),{ }^{4} \mathrm{~A}_{2} \rightarrow{ }^{4} \mathrm{~T}_{1}(\mathrm{~F})$ & 4.63 \\
$\mathrm{Ni}(\mathrm{TM})_{2}$ & $377(26525)$ & $700(14.286)$ & $780(12.820)$ & & ${ }^{3} \mathrm{~A}_{2 \mathrm{~g}} \rightarrow{ }^{3} \mathrm{~T}_{2 \mathrm{~g}},{ }^{3} \mathrm{~A}_{2 \mathrm{~g}} \rightarrow{ }^{3} \mathrm{~T}_{1 \mathrm{~g}}$ & 1.29
\end{tabular}

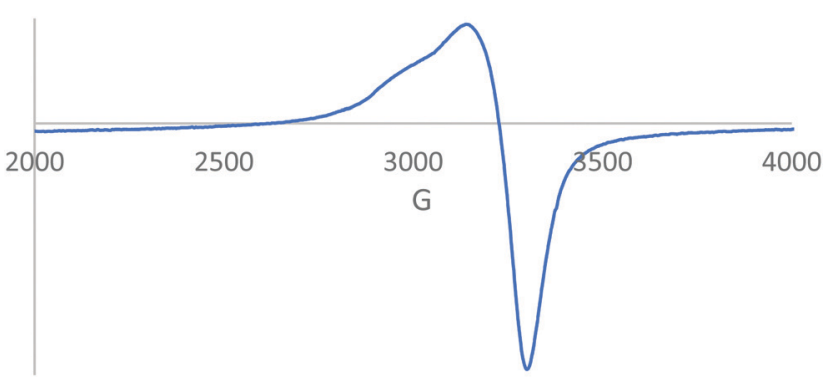

Fig. 3 Powdered EPR spectrum of $\mathrm{Cu}-\mathrm{TM}$ at room temperature.

range of $20-30 \%$. The final stage started between 350 and $600{ }^{\circ} \mathrm{C}$, and the maximum temperature produced a metal oxide as the final product.

In contrast, the $\mathrm{Co}(\mathrm{II})$ compound showed only two decomposition steps. In the first step, starting at $147-246{ }^{\circ} \mathrm{C}$, it lost $20.7 \%$ of its mass. The second step occurred at $327-$ $436{ }^{\circ} \mathrm{C}$, with a gradual but minor mass loss that resulted in a metal oxide with $45.85 \%$. Interestingly, $\mathrm{Zn}$-TM was stable up to $\sim 260{ }^{\circ} \mathrm{C}$ in atmospheric air; then it decomposed in a single stage. The decomposition was indicated by the DTG peak and the corresponding endothermic reaction. All the final products had some amount of hydrocarbon with the metal oxide as the final residue. The thermal degradation behavior of the metal complexes is presented in Fig. 4. The thermal mass loss and decomposition stages are illustrated in Table 6 . These results agree with the speculated formulas for the coordinated compounds.

\subsection{Thermodynamics}

The thermodynamic parameters of the ligand and complexes were calculated by employing two methods, the Coast-Redfern integral $^{49}$ and the approximation of Horowitz-Metzger, ${ }^{50}$ to obtain the activation energy $\left(E_{\mathrm{a}}\right)$. Next, thermodynamic activation parameters, namely the activation enthalpy $(\Delta H)$, activation entropies $(\Delta S)$ and $\Delta G$ Gibbs free energy, were calculated using the relationships

$$
\begin{gathered}
\Delta H=E-R T, \\
\Delta S=R[\operatorname{In}(A h / k T)] \\
\Delta G=\Delta H-T \Delta S,
\end{gathered}
$$

and

where $k$ is Boltzmann's constant and $h$ is Planck's constant. Their values for each step are summarized in Tables S2 and S3 (ESI $\dagger$ ), and the drawn relation of both methods is presented for the individual complexes.

The thermodynamic behavior of all complexes of TM with transition metal ions is a non-spontaneous and slow reaction due to the negative values of $\Delta S .^{51,52}$ The $E_{\mathrm{a}}$ values increased at the second stage for all compounds, and then reduced after degradation, which indicates high stability of the complexes. Moreover, the reactions were endothermic $(\Delta H>0)$ and endergonic $(\Delta G>0)$ (Table 5$).{ }^{53}$

\subsection{Molecular orbital calculations}

3.8.1 Geometry of the complexes. The ligand and the metal complexes were also studied using DFT calculations in order to

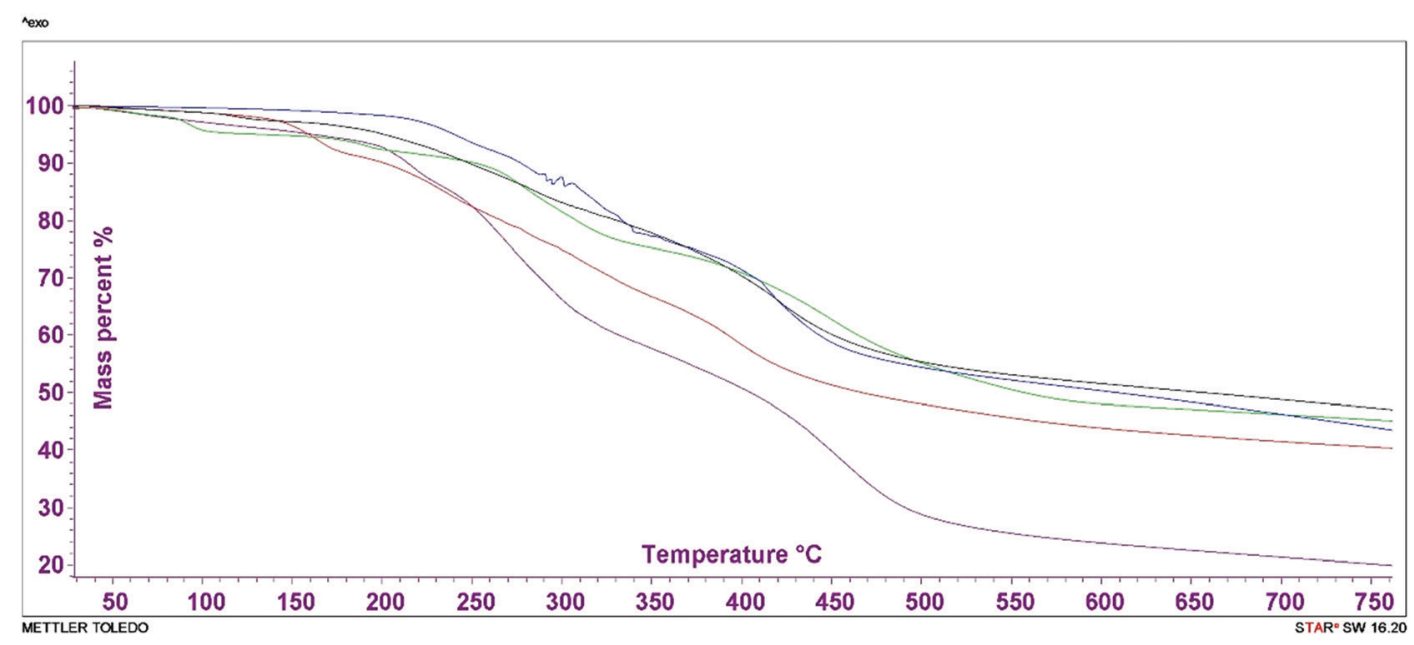

Fig. 4 TG curves of the Fe-TM, Co-TM, Cu-TM, Ni-TM and $\mathrm{Zn}-\mathrm{TM}$ complexes. 
Table 5 Thermal data for the TM metal complexes

\begin{tabular}{|c|c|c|c|c|c|c|}
\hline Complex & Step & $\begin{array}{l}\text { Temp. } \\
\text { range }\end{array}$ & $\begin{array}{l}\text { Weight loss \% found } \\
\text { (calc.) }\end{array}$ & Assignments & $\begin{array}{l}\text { Total mass loss } / \% \text { found } \\
\text { (calc.) }\end{array}$ & $\begin{array}{l}\text { Final solid state } \\
\text { residue }\end{array}$ \\
\hline $\mathrm{Cu}-\mathrm{TM}$ & 1st & $166-200$ & $12.7(12.9)$ & $\mathrm{Cl}_{2}+\mathrm{CO}$ & $65.9(66.3)$ & $\begin{array}{l}\mathrm{CuO}+10 \mathrm{C}, \\
25.6(25.69)\end{array}$ \\
\hline \multirow[t]{3}{*}{$\mathrm{Fe}-\mathrm{TM}$} & 1st & 169-202 & $9.1(9.3)$ & $2 \mathrm{HCl}$ & \multirow[t]{3}{*}{$66.4(67.0)$} & \multirow[t]{3}{*}{$\mathrm{Fe}_{2} \mathrm{O}_{3}+10 \mathrm{C}, 35.7(36)$} \\
\hline & 2nd & $207-218$ & $28.3(28.6)$ & $4 \mathrm{C}_{2} \mathrm{H}_{2}+2 \mathrm{NO}+2 \mathrm{HCl}$ & & \\
\hline & $3 \mathrm{rd}$ & $352-390$ & $29(29.1)$ & $2 \mathrm{SO}_{2}+2 \mathrm{CO}_{2}$ & & \\
\hline & 3rd & $384-664$ & $33.5(34)$ & $2 \mathrm{C}_{2} \mathrm{H}_{2}+2 \mathrm{SO}_{2}+2 \mathrm{CO}_{2}$ & $65.4(66.7)$ & $\mathrm{NiO}+12 \mathrm{C}, 32.3(32.9)$ \\
\hline \multirow[t]{2}{*}{ Co-TM } & 1st & $147-246$ & $20.3(20.7)$ & $2 \mathrm{NO}+2 \mathrm{HCl}+\mathrm{C}_{2} \mathrm{H}_{4}$ & \multirow[t]{2}{*}{$46.7(46.9)$} & \multirow[t]{2}{*}{$\mathrm{CoO}+12 \mathrm{C}, 45.85(45.6)$} \\
\hline & 2nd & $327-436$ & $26.4(26.2)$ & $2 \mathrm{CO}_{2}+2 \mathrm{SO}_{2}+2 \mathrm{HCl}$ & & \\
\hline $\mathrm{Zn}-\mathrm{TM}$ & $\begin{array}{l}\text { One } \\
\text { step }\end{array}$ & $259-303$ & $51.9(52.5)$ & $\begin{array}{l}7 \mathrm{C}_{2} \mathrm{H}_{2}+2 \mathrm{SO}_{2}+2 \mathrm{NO}+4 \mathrm{HCl}+ \\
4 \mathrm{H}_{2} \mathrm{O}\end{array}$ & $51.9(52.5)$ & $\mathrm{ZnO}+10 \mathrm{C}, 33.61(33.6)$ \\
\hline
\end{tabular}

obtain the optimum geometries and compare them with the experimental values. Investigation results from elemental analysis, spectroscopic analysis (IR and ${ }^{1} \mathrm{H}-\mathrm{NMR}$ ), and TGA confirmed the optimized structures, which are shown with the atom numbers and labels in Fig. 5.

Selected geometric parameters around the coordination sphere were extracted as bond lengths and bond angles for the free ligand and its metal complexes and are tabulated in Table 6.

In the metal complexes, the bond lengths of $\mathrm{C} 11-\mathrm{O} 12$ and C12-C14 were longer than the free ligand by 0.01-0.02 $\AA$. The bond length of C11-O13 was compressed after coordination to the metal ions while C12-N16 elongated after binding to the metal. The $\mathrm{M}-\mathrm{O}$ bonds between the metal and free ligand site
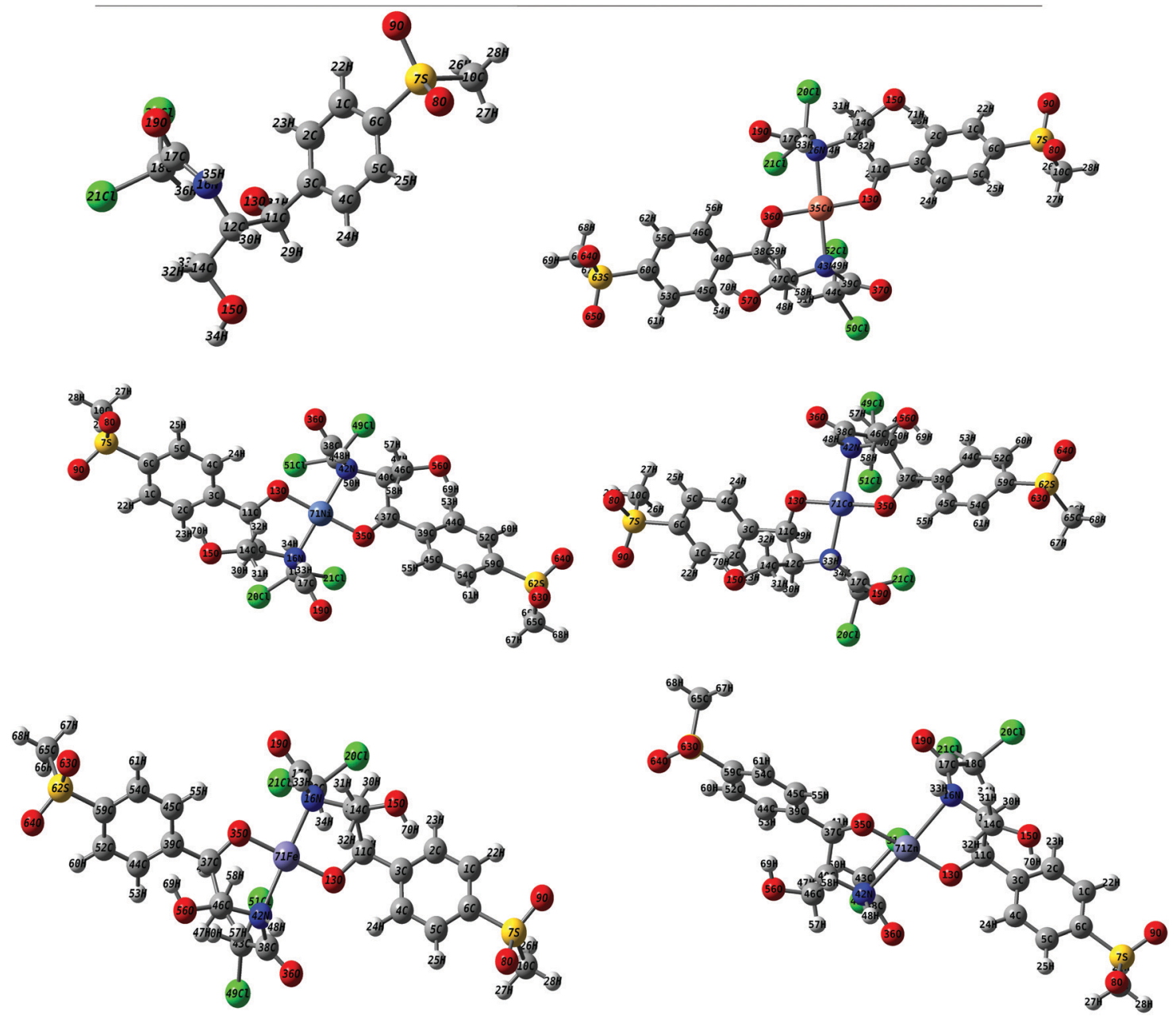

Fig. 5 The optimized geometry and numbering system for TM and its metal complexes. 
Table 6 Selected geometric bond lengths, bond angles, and dihedral angles of the optimized ligand and its complexes

\begin{tabular}{|c|c|c|c|c|c|c|}
\hline & TM & $\mathrm{Cu}-\mathrm{TM}$ & Co-TM & $\mathrm{Ni}-\mathrm{TM}$ & $\mathrm{Fe}-\mathrm{TM}$ & $\mathrm{Zn}-\mathrm{TM}$ \\
\hline \multicolumn{7}{|l|}{ Bond lengths } \\
\hline $\mathrm{C} 11-\mathrm{C} 12$ & 1.55 & 1.56 & 1.58 & 1.57 & 1.57 & 1.58 \\
\hline C12-C14 & 1.53 & 1.54 & 1.54 & 1.54 & 1.54 & 1.54 \\
\hline C12-N16 & 1.48 & 1.51 & 1.51 & 1.53 & 1.52 & 1.49 \\
\hline C11-O13 & 1.46 & 1.38 & 1.38 & 1.39 & 1.39 & 1.39 \\
\hline N16-M & - & 2.16 & 1.99 & 1.95 & 2.03 & 2.46 \\
\hline O13-M & - & 1.84 & 1.81 & 1.92 & 1.84 & 1.82 \\
\hline O35-M & - & 1.84 & 1.81 & 1.82 & 1.85 & 1.82 \\
\hline N43-M & - & 2.16 & 1.99 & 1.96 & 2.08 & 2.40 \\
\hline \multicolumn{7}{|l|}{ Bond angles } \\
\hline O13-C11-C12 & 107 & 110.67 & 110.23 & 110.76 & 110.63 & 110.49 \\
\hline N16-C12-C11 & 105 & 106.81 & 107.0 & 105.59 & 108.89 & 108.31 \\
\hline O13-M-N16 & - & 84.35 & 88.36 & 87.9 & 86.14 & 80.80 \\
\hline O13-M-N43 & - & 95.02 & 92.5 & 92.39 & 93.82 & 101.45 \\
\hline N42-M-O35 & - & 84.84 & 84.12 & 87.35 & 85.43 & 81.65 \\
\hline N16-M-O35 & & 95.35 & 94.6 & 92.30 & 94.21 & 100.05 \\
\hline \multicolumn{7}{|l|}{ Dihedral angles } \\
\hline M-O13-C11-H29 & - & -63.25 & -66.9 & -71.86 & -88.79 & -64.69 \\
\hline M-O35-C38-H42 & - & -66.89 & -70.7 & -68.45 & -72.83 & -63.20 \\
\hline M-O13-C11-C12 & - & 53.54 & 29.26 & 45.16 & 28.74 & -52.76 \\
\hline M-N16-C12-C11 & - & 22.16 & 27.35 & 24.77 & 35.16 & 31.08 \\
\hline M-N43-C41-C38 & - & 26.68 & 25.68 & 20.20 & 29.81 & 25.88 \\
\hline
\end{tabular}

were in the reported metal to oxygen range,${ }^{54}$ which reflected the ionic character of these bonds. In contrast, the covalent bond between the metal and $\mathrm{NH}$ group showed a range of small and medium ionic character (bond length $\geq 2 \AA$ ).

There was a practical change of the bond angles after coordination with the transition metals. The bond angles O13-C11-C12 and N16-C12-C11 increased by $0.03-0.04^{\circ}$ due to the electric repulsion after complexing. Moreover, the angles around the respective central metal ion indicated that the complex adopted a distorted tetrahedral geometry, ${ }^{55,56}$ as observed for $\mathrm{Cu}(\mathrm{II})$ and $\mathrm{Zn}$ (II), and the values of the bond angles of $\mathrm{O}-\mathrm{M}-\mathrm{N}$ emphasized this distortion. The complexes of $\mathrm{Fe}(\mathrm{II})$, $\mathrm{Ni}(\mathrm{II})$ and $\mathrm{Co}(\mathrm{II})$ suggested a highly distorted tetrahedral arrangement around the metal.

In addition, the dihedral angles around the metal ions were far from $0^{\circ}$ or $180^{\circ}$. Thus, the metal ions in the studied compounds are not in the same molecular plane as the donating sites.

3.8.2 Global reactivity descriptors of the ligand and its complexes. Studying the molecular orbital compositions and energy levels of a molecule is a practical approach to describe the electronic characteristics of molecular systems. ${ }^{13}$ Frontier molecular orbital (FMO) maps were generated via the HOMO and LUMO for the studied ligand and its complexes in the ground state and are presented in Fig. 6. The molecular orbital diagrams for the ligand showed that the HOMO orbitals are distributed mainly over most of the ligand molecule while the LUMO orbitals are located on the acetamide group and $\mathrm{Cl}$ atoms. The extracted values for the HOMO and LUMO for the metal complexes are tabulated with the essential quantum parameters in Table 7. The difference between the orbital energies gives the energy gap, $E_{\mathrm{g}}$, which is a good indicator of molecule hardness and softness: ${ }^{57}$ a small $E_{\mathrm{g}}$ indicates soft and reactive complexes, and vice versa. Therefore, $E_{\mathrm{g}}$ decreased after coordination to the metal ions by stabilizing the HOMO orbitals for the complexes. Among the metal complexes, $\mathrm{Cu}-\mathrm{TM}$ was the softest compound, with a small $E_{\mathrm{g}}, 3.15 \mathrm{eV}$. The absolute hardness values $(\eta)$ for the investigated compounds could be arranged as: $\mathrm{TM}>\mathrm{Co}$ (II) $>\mathrm{Zn}$ (II) $>\mathrm{Ni}$ (II) $>\mathrm{Fe}$ (II) $>\mathrm{Cu}(\mathrm{II})$, and the absolute softness $(\sigma)$ values as: $\mathrm{Cu}$ (II) $>\mathrm{Zn}$ (II) $>\mathrm{Fe}$ (II) $>$ $\mathrm{Ni}$ (II) $>\mathrm{Co}$ (II) $>\mathrm{TM}$. Thus, the Cu complex had the lowest $\eta$ and the maximum $\sigma$ values, which indicates high reactivity. The negative chemical potential (Pi) of the metal complexes indicates a spontaneous addition process. Moreover, the electrophile was able to obtain electronic charge from other molecules and increase the biological activity descriptor. $\mathrm{Cu}-\mathrm{TM}$ had the highest electrophilicity index among the other complexes, Table 7, which suggests favourable toxicity and inhibition activity. ${ }^{58}$

3.8.3 Natural charges and natural population. Studying the electronic characteristics of complexes by estimating the atomic charges emphasizes the electrophilic and nucleophilic sites in the molecules. The natural bond orbital (NBO) charges of the coordinated atoms in the free ligand TM and its metal complexes are illustrated in Table 8 , and the natural electronic configurations of the metal ions in the coordination sphere are presented in Table 9.

In the TM ligand, most electronegative charges were found positioned on the oxygen of sulfonyl, primary and secondary alcohol, and carboxamide. The two alcohol oxygens were more electronegative $(-0.765,-0.786)$ than the carboxamide group $(-0.636,-0.592)$ and could be possible donating atoms that could react with the electropositive metal ions $\mathrm{Cu}(\mathrm{II}), \mathrm{Co}(\mathrm{II})$, $\mathrm{Ni}(\mathrm{II}), \mathrm{Fe}(\mathrm{II})$ and $\mathrm{Zn}$ (II) by ionic bonds. In this complex, the $\mathrm{NH}$ group donated its electron via a covalent bond.

All the studied first row transition metal ions in the complexes have a +2 oxidation state, but the calculated natural charges for $\mathrm{Cu}^{+0.50}, \mathrm{Ni}^{+0.01}, \mathrm{Zn}^{+0.01}$ and $\mathrm{Co}^{+0.50}$ were lower than +2 due to receipt of electrons from the ligand..$^{55}$ Additionally, Table 9 shows that the metal ions received varied electrons from the ligand: the highest ion that received $1.43 \mathrm{e}$ was $\mathrm{Zn}\left(\mathrm{d}^{9.53}\right)$, while $\mathrm{Ni}-\mathrm{TM}\left(\mathrm{d}^{8.53}\right)$ received $1.26 \mathrm{e}$, and $\mathrm{Cu}-\mathrm{TM}\left(\mathrm{d}^{9.29}\right)$ had fewer electrons $(0.67)$. Co-TM $\left(\mathrm{d}^{3.26}\right)$ was $>$ Fe-TM and received $0.79 \mathrm{e}\left(\mathrm{d}^{6.44}\right)$ from the ligand.

\subsection{Biological studies}

3.9.1 CT-DNA binding study. The DNA binding ability of the metal complexes was measured using UV-absorption by adding various concentrations of CT-DNA. The maximum absorption band for the fixed-concentration solution in DMSO for the metal-TM compounds in the range $263-270 \mathrm{~nm}$ had a red shift and hyperchromic molar absorptivity, indicating strong binding to DNA (Fig. 7). This proves three changes:

(1) The modification of the structure of the target DNA after adding the metal complexes. ${ }^{59}$

(2) Charged cations in the process bind to the phosphate group in DNA by electrostatic attraction, thus damaging the secondary structure of the DNA. ${ }^{60}$

(3) Unraveling of the helix structure of DNA by external contact or partial effects, causing more bases of the DNA to unravel. $^{61}$ 


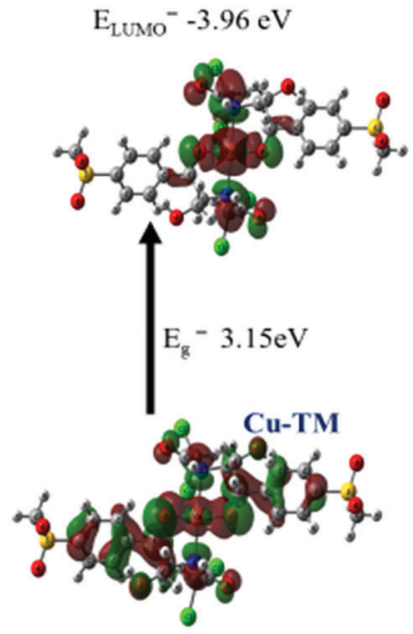

$\mathrm{E}_{\text {HOMO }}{ }^{-}-7.11 \mathrm{eV}$
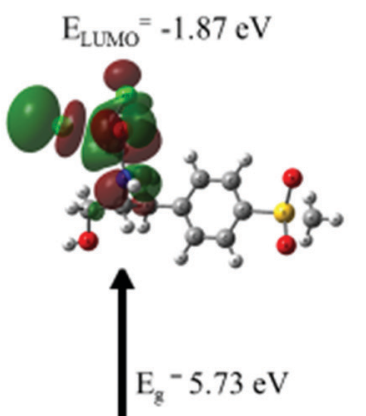

TM

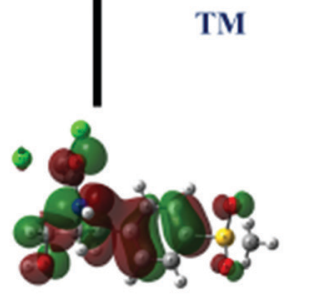

$\mathrm{E}_{\text {HOMO }}{ }^{-}-7.607 \mathrm{eV}$

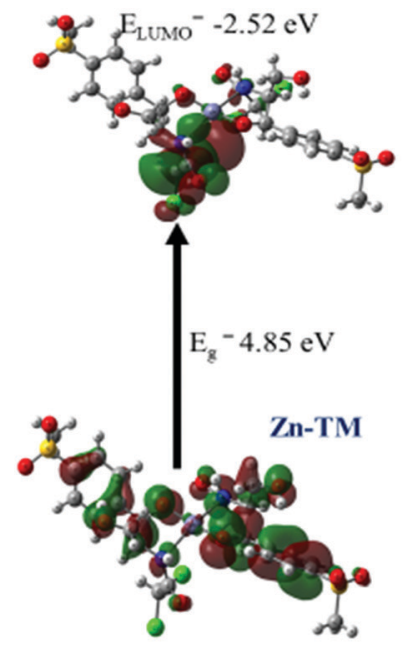

$\mathrm{E}_{\text {HOMO }}{ }^{-}-7.37 \mathrm{eV}$

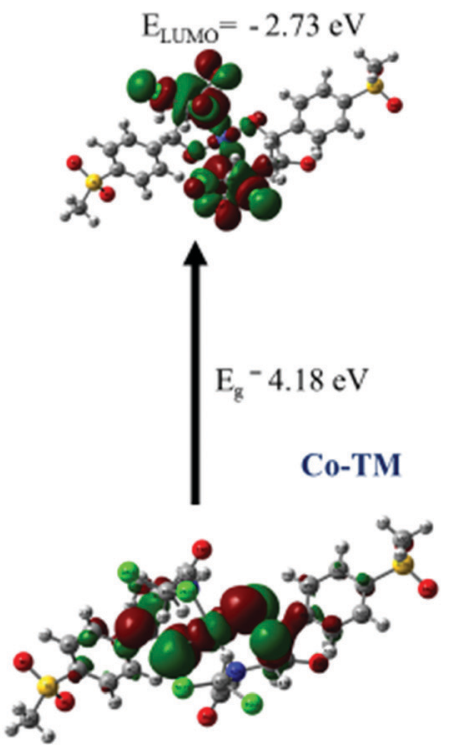

$\mathrm{E}_{\text {HOMO }}{ }^{-}-6.91 \mathrm{eV}$

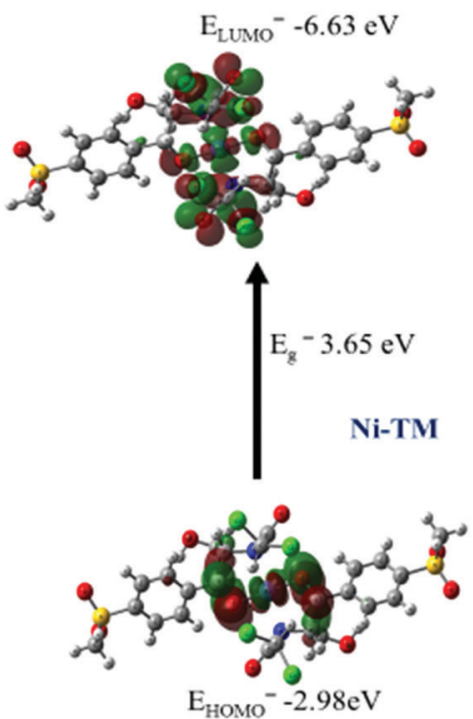

$\mathrm{E}_{\text {LUMO }}{ }^{-}-2.70 \mathrm{eV}$
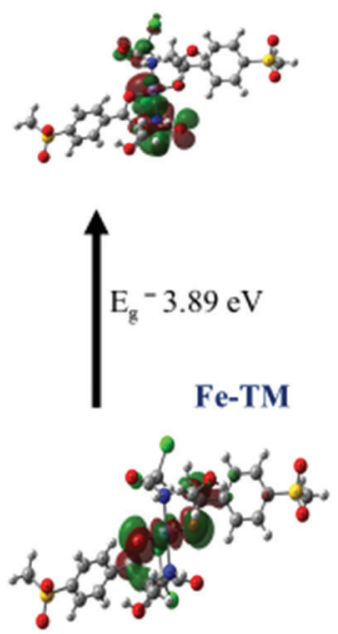

$\mathrm{E}_{\text {HOMO }}{ }^{-}-6.59 \mathrm{eV}$

Fig. 6 HOMO and LUMO charge density maps of the studied complexes using the B3LYP/LAND level.

Table $7 E_{\text {HOMO }} E_{\text {LUMO }}, E_{\mathrm{g}}$ and the quantum parameters for the ligand and its complexes using B3LYP/LAND

\begin{tabular}{llllllrrrrr}
\hline Compound & HUMO & LUMO & $\Delta E$ & $x$ & $\eta$ & \multicolumn{1}{c}{ Pi } & \multicolumn{1}{c}{$\sigma$} & \multicolumn{1}{c}{$S$} & $\omega$ \\
TM & -7.61 & -1.87 & 5.73 & 4.74 & 2.87 & -4.74 & 0.35 & 1.43 & 3.92 \\
Ni-TM & -6.64 & -2.98 & 3.65 & 4.81 & 1.83 & -4.81 & 0.91 & 0.91 & 2.40 & 2.65 \\
Co-TM & -6.91 & -2.73 & 4.18 & 4.82 & 2.09 & 0.48 & -4.82 & 1.05 & 1.05 & 2.41 \\
Zn-TM & -7.37 & -2.53 & 4.85 & 4.95 & 2.42 & -4.95 & 1.21 & 1.21 & 2.48 & 2.04 \\
Cu-TM & -7.12 & -3.97 & 3.15 & 5.54 & 1.57 & -5.54 & 1.30 & 0.79 & 2.77 & 3.52 \\
Fe-TM & -6.59 & -2.70 & 3.89 & 4.64 & 1.95 & -4.64 & 0.97 & 0.97 & 2.32 & 2.38 \\
\hline
\end{tabular}

However, the TM ligand and the Fe(II) complex had adverse behavior as well, showing a blue shift and hypochromic absorptivity, indicating weak intercalation to the base pairs of DNA $^{62}$ (Fig. 7b).
The computed binding constant $\left(K_{\mathrm{b}}\right)$ and absorption data of the metal-TM complexes are listed in Table $\mathrm{S} 4$ (ESI $\dagger$ ). According to the literature, the range of $10^{5}-10^{11}$ reflects an intercalator binding type, which is less cytotoxic and could be 
Table 8 NBO charges calculated for the metal complexes using B3LYP/ LAND

\begin{tabular}{llrrrrr}
\hline & TM & Cu-TM & Co-TM & Ni-TM & Fe-TM & Zn-TM \\
\hline O13 & -0.765 & -0.933 & -0.854 & -0.867 & -0.894 & -1.00 \\
O15 & -0.786 & -0.716 & -0.795 & -0.715 & -0.715 & -0.714 \\
N16 & -0.592 & -0.762 & -0.863 & -0.747 & -0.754 & -0.741 \\
O19 & -0.636 & -0.929 & -0.796 & -0.492 & -0.501 & -0.540 \\
M & - & 1.344 & 0.767 & 1.09 & 1.204 & 1.568 \\
\hline
\end{tabular}

promising therapeutically. ${ }^{59,63}$ The $\Delta G$ values indicate high spontaneous binding of the metal compounds to DNA. ${ }^{18}$ The investigated compounds in order of intercalative mode are arranged as follows: $\mathrm{Zn}$ (II) $>\mathrm{Cu}(\mathrm{II})>\mathrm{Ni}(\mathrm{II})$.

3.9.2 In vitro binding study with human serum albumin (HSA). Serum albumin constitutes $\sim 55 \%$ of the total blood plasma protein and plays a role in the transportation of drugs (e.g., metal complexes) and metabolism. ${ }^{64,65}$ We investigated the morphological changes in the secondary structure of HSA upon complex formation between the drug and HSA by electronic absorption spectroscopy. Protein-ligand complex formation can be estimated by the difference change in absorbance before and after the incremental addition of the metal complex. Fig. 8 illustrates the UV absorption spectra of HSA in the absence and presence of $\mathrm{TM}-\mathrm{Cu}$, while that for the TM-Zn complex is shown in Fig. S2 (ESI $\dagger$ ). Generally, the absorption peak of HSA at $280 \mathrm{~nm}$ is attributed to the protein chromophores phenylalanine, tyrosine, and tryptophan, which have absorbance at 260, 270 and $280 \mathrm{~nm}$, respectively. ${ }^{64,66} \lambda_{\text {max }}$ of free HSA at $280 \mathrm{~nm}$ was blue shifted to $273 \mathrm{~nm}$ in both the $\mathrm{Cu}$ (II) and $\mathrm{Zn}$ (II) complexes. A sharp increase in absorption intensity, which is a hyperchromism effect, was observed after incremental titration of TM-Cu with HSA, while TM-Zn presented a hypochromic effect. The results demonstrate

Table 9 Calculated natural charge, natural population and natural electronic configuration of the metals in the studied complexes using the B3LYP/ LAND level

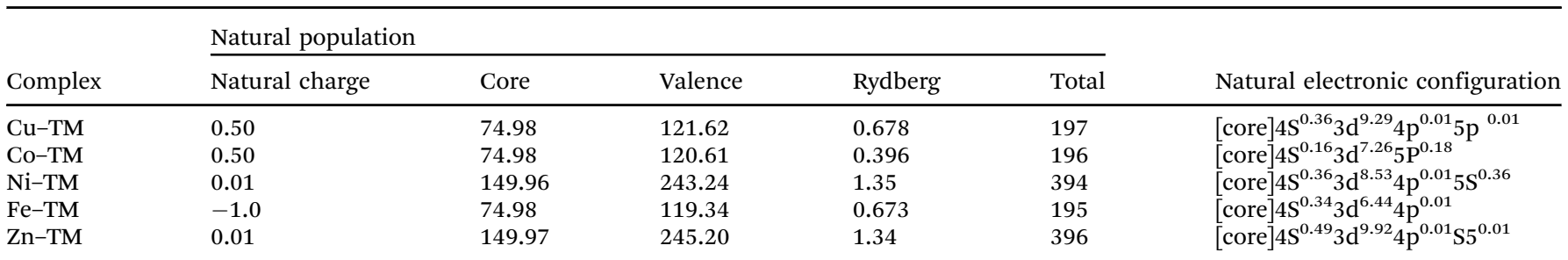
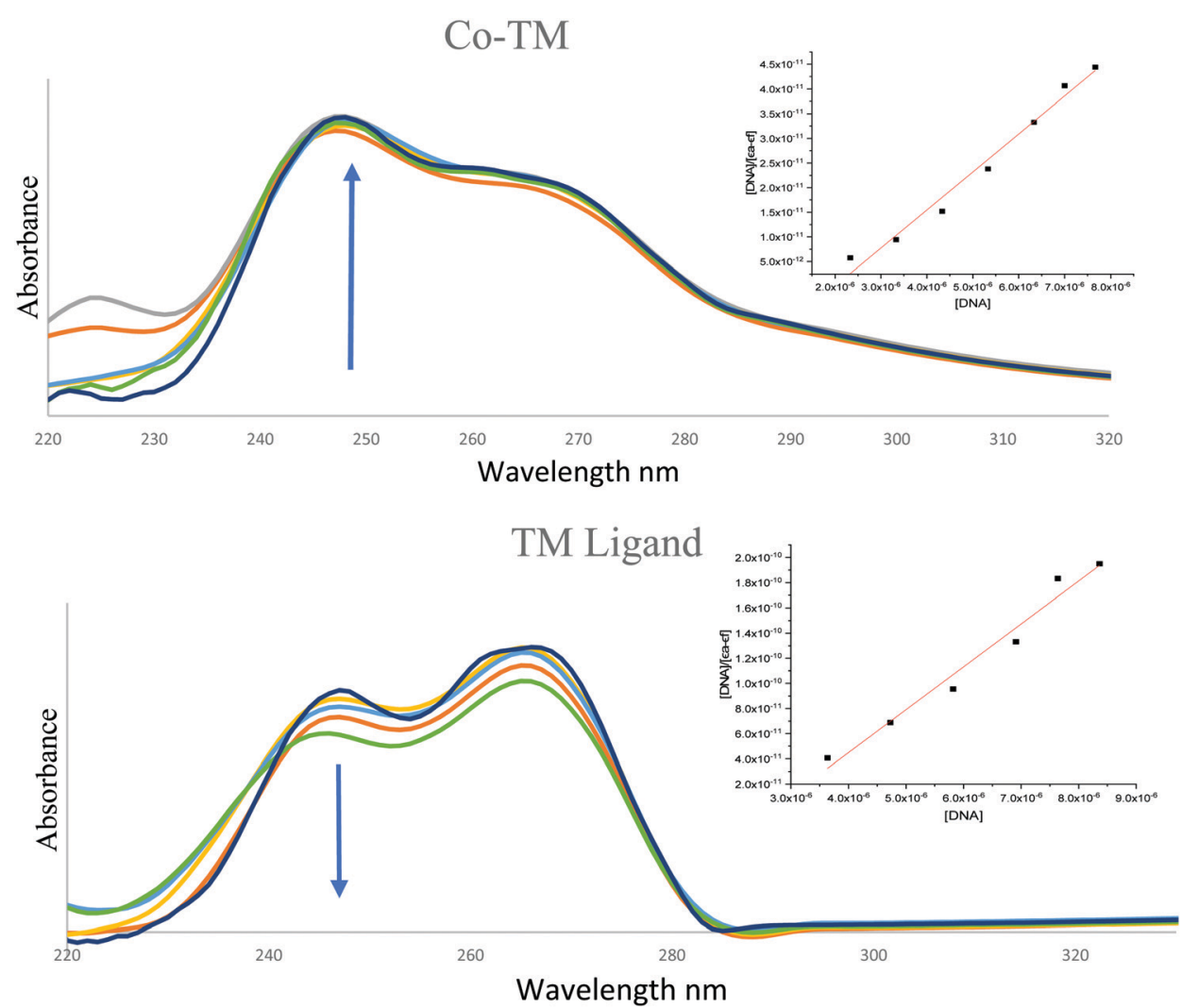

Fig. 7 The hypochromic and hyperchromic reactions of (a) Co-TM and (b) the TM ligand (arrows indicate changes with increasing DNA concentration). 


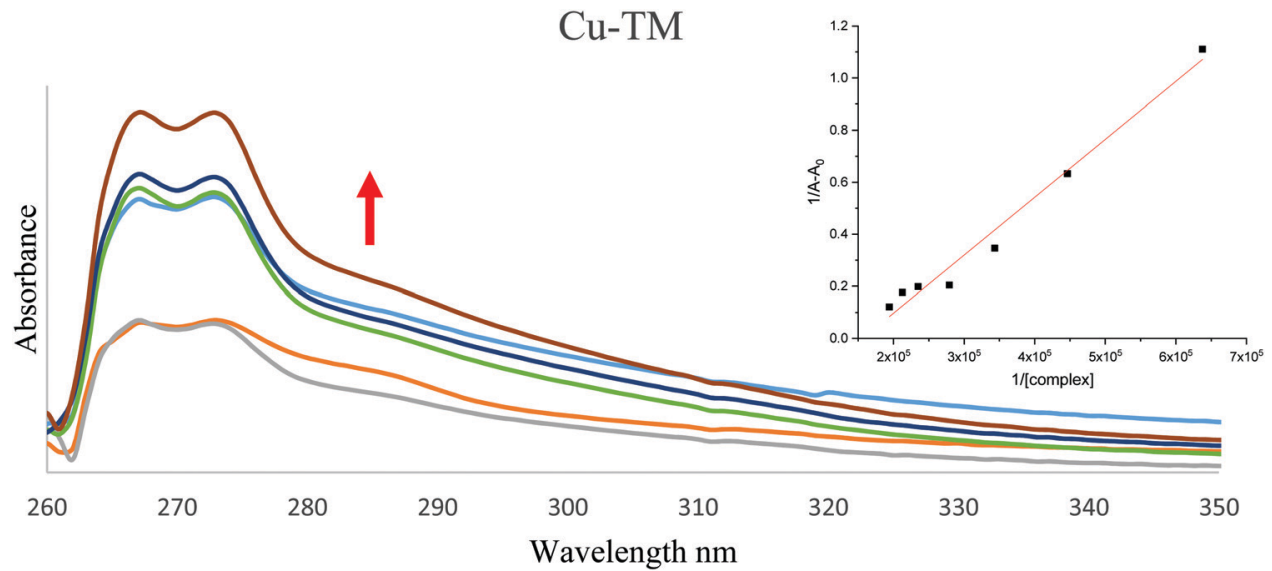

Fig. 8 The change in the UV-vis absorption spectra of HSA in the absence and presence of different concentrations of metal complexes at pH 7.2 and $25^{\circ} \mathrm{C}$.

practical changes in the micro-environment of the tryptophan residues ${ }^{67}$ leading to reduced extension of the peptide strands. The observed alteration resulted from non-covalent interactions of the metal complex with HSA such as electrostatic attraction or by hydrogen-bond formation. ${ }^{64}$ The calculated intrinsic binding constants $\left(K_{\mathrm{b}}\right)$ of complexes TM-Cu and TM-Zn with HSA were $1.74 \times 10^{5}$ and $9.87 \times 10^{5} \mathrm{M}^{-1}$, respectively. The $K_{\mathrm{b}}$ values suggested that both complexes have practical binding propensity with HSA, and that TM-Zn has higher binding susceptibility due to conformational changes in the HSA structure.

3.9.3 Cytotoxicity. The in vitro cytotoxicity of the metal-TM complexes was tested against a human colon carcinoma (HCT-116) cell line and a human breast carcinoma (MCF-7) cell line. Their performance was compared to cisplatin, an anticancer chemotherapy drug, within the $0-500 \mu \mathrm{g} \mathrm{ml} \mathrm{m}^{-1}$ concentration range. The standard deviation for the $50 \mu \mathrm{g} \mathrm{ml}^{-1}$ sample and $\mathrm{IC}_{50}$ are listed in Table 10. The obtained results are the average of three replicate experiments, with \pm standard deviation (SD) indicated. The results (Fig. 8) revealed that most complexes displayed greater cytotoxicity than the TM ligand. Moreover, the Zn(II) complex showed the highest cytotoxicity, with an $\mathrm{IC}_{50}$ value of $28.6 \mu \mathrm{g} \mathrm{ml}{ }^{-1}$ for the MCF-7 cell line and $55.2 \mu \mathrm{g} \mathrm{ml}^{-1}$ for the HCT-116 cell line. Although the $\mathrm{IC}_{50}$ value is lower than for cisplatin, the results indicate that changing the nature of the metal ion impacted its biological activity. The $\mathrm{Cu}$ (II) complex was the next most cytotoxic, with a medium

Table 10 Cytotoxicity of TM and its metal complexes for MCF-7 and HCT-116. Shown is the mean of three replicates \pm standard deviation

\begin{tabular}{llllll}
\hline & \multicolumn{2}{l}{ S.D. $( \pm)$} & & \multicolumn{2}{c}{$\mathrm{IC}_{50}\left(\mu \mathrm{g} \mathrm{m} \mathrm{ml}^{-1}\right)$} \\
\cline { 2 - 3 } Complex & MCF-7 & HCT-116 & & MCF-7 & HCT-116 \\
\hline TM & 3.84 & 3.79 & $475 \pm 9.8$ & $426 \pm 9.2$ \\
Cu-TM & 0.78 & 0.95 & & $48.8 \pm 0.92$ & $60.5 \pm 1.8$ \\
Ni-TM & 1.31 & 0.94 & & $92.5 \pm 2.7$ & $57.5 \pm 1.5$ \\
Zn-TM & 0.69 & 0.73 & & $28.6 \pm 0.38$ & $55.2 \pm 1.6$ \\
Co-TM & 0.97 & 0.87 & & $106 \pm 1.9$ & $81.6 \pm 2.1$ \\
Fe-TM & 1.82 & 2.93 & & $208 \pm 4.3$ & $216 \pm 4.5$ \\
Cisplatin & 0.12 & 0.07 & & 5.71 & 2.43
\end{tabular}

$\mathrm{IC}_{50}$ value compared to the other metal compounds against the breast cancer cells. This could be due to the focal metal atom; according to Tweedy's chelation theory, the prediction of a metal atom's polarity is reduced after chelation due to partial sharing of the metal's positive charge with the donor groups, resulting in delocalization of the electron over the chelation ring. Therefore, the lipophilic nature of the chelates increases and smooths permeation through the cell membrane (Fig. 9). ${ }^{68,69}$

3.9.4 Molecular docking. The synthesized metal complexes exhibited diverse cytotoxicity effects, as shown in Table 10. Interestingly, the $\mathrm{Zn}$ (II) and $\mathrm{Cu}(\mathrm{II})$ compounds with TM exerted high anticancer activities. Therefore, we performed a docking process for these two complexes with a colon protein (ID: 4FM9) and a breast protein (ID: $1 \mathrm{H} 7 \mathrm{~K}$ ), which were chosen from the literature, to investigate the binding mode and the conformation structure that contributes to the interaction between the proteins and the complexes.

Tables S5 and S6 (ESI $\dagger$ ) reveal the following results:

(1) Both complexes have a higher negative score of free binding energy than the free ligand, indicating that the metal ion overlapped with the ligand orbitals upon chelation and

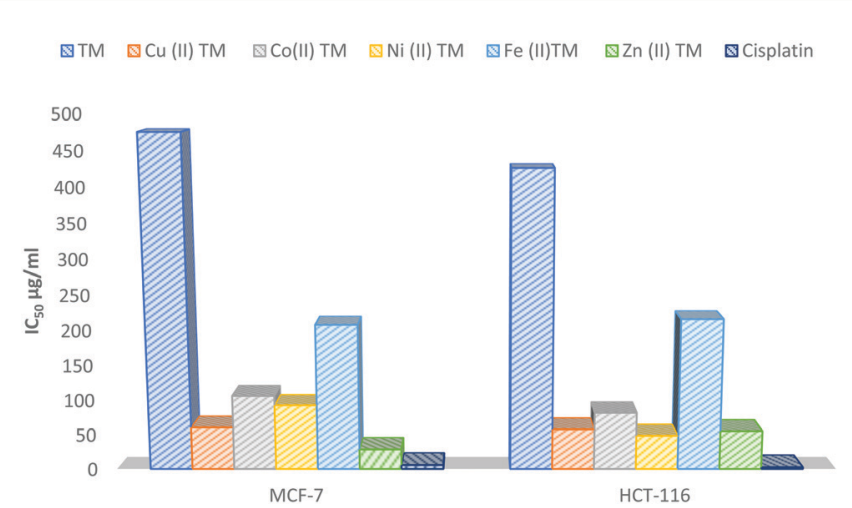

Fig. $9 \quad I_{50}$ values of the TM ligand and its metal complexes against a human breast carcinoma (MCF-7) cell line and a human colon carcinoma (HCT-116) cell line. 
Table 11 Molecular docking mode and interaction for the TM ligand, the Cu(I) complex, and the Zn(II) complex with the (4FM9) colon protein and (1H7K) breast protein

Protein 2D 3D

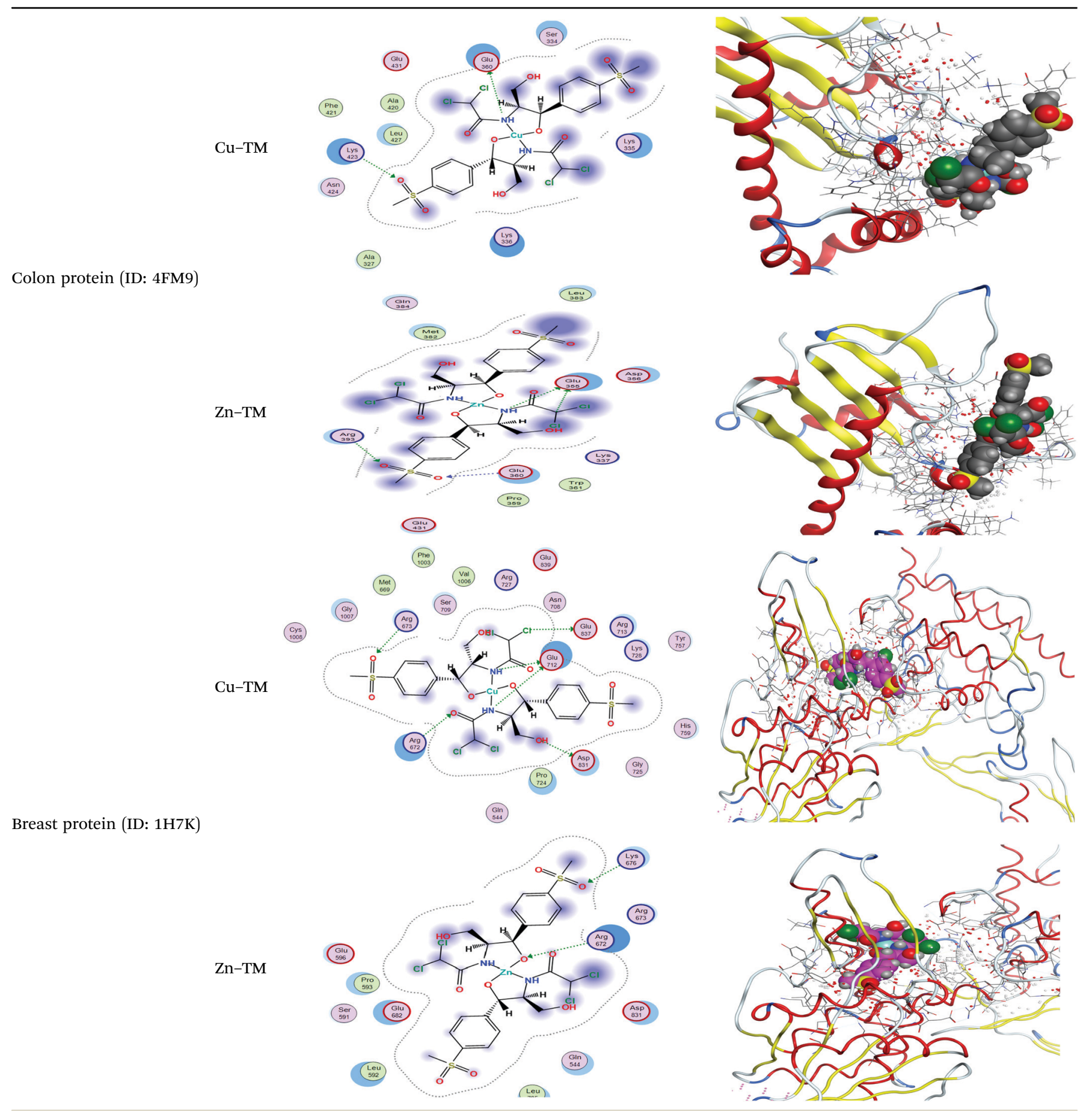

reduced the metal polarity, thus increasing the lipophilicity and penetration through the lipid plasma membrane. ${ }^{69-71}$

(2) The docking score values for $\mathrm{Cu}(\mathrm{II})$ and $\mathrm{Zn}$ (II) against colon receptors were -8.18 and $-9.22 \mathrm{kcal} \mathrm{mol}^{-1}$, respectively.

(3) The colon protein (4FM9) interacted via amino acid pocket molecules with $\mathrm{Cu}(\mathrm{II})$ through $\mathrm{SO}_{2}$ oxygen and $\mathrm{NH}$ groups by donating their $\mathrm{H}$ atoms or accepting $\mathrm{H}$ atoms.
The $\mathrm{H}$ contact between the methyl group in $\mathrm{Zn}-\mathrm{TM}$ and an amino residue increased the binding with this protein compared to the $\mathrm{Cu}(\mathrm{II})$ complex.

(4) Similarly, the breast protein $(1 \mathrm{H} 7 \mathrm{~K})$ docking score was $-7.09 \mathrm{kcal} \mathrm{mol}^{-1}$, which resulted in the interaction with the $\mathrm{Cu}-\mathrm{TM}$ complex by donating different amino acid hydrogens forming $\mathrm{H}$ bonds with $\mathrm{Cl}$ and $\mathrm{O}$ ions and the two $\mathrm{NH}$ groups, 
whereas Zn-TM showed H-accepting interactions with ARG 672 and Lys 675, as shown in Table 11.

(5) Increasing the interaction between the complex molecules and the receptors might increase the docking scores and prove the in vitro inhibition activities (Table S6, ESI $\dagger$ ). The best possible conformations of the two compounds inside the protein minor groove are presented in Table 11.

\section{Conclusion}

New complexes of divalent transition metals of the antibiotic thiamphenicol were successfully synthesized. All prepared complexes were characterized by various analytical techniques such as IR, EPR, elemental analysis, and thermal analysis. The IR and ${ }^{1} \mathrm{H}-\mathrm{NMR}$ results confirmed that a metal cation was coordinated to the one deprotonated alcohol and $\mathrm{NH}$ atom. The electronic spectrum of the Ni-TM complex at 14.286 and $12.820 \mathrm{~cm}^{-1}$ and the low magnetic moment value indicated the square planar geometry around the ion metal. The electronic spectrum of the Fe-TM complex did not show absorption in the UV-vis range, which indicates a tetrahedral geometry. The observed color of the complex is due to the charge transfer transitions, which presented as an overlapped band at $390 \mathrm{~nm}$ in the spectrum. The solid sample of $\mathrm{Cu}$ (II) displayed $g_{\|}$(2.32) $>g_{\perp}$ (2.07) values, indicating a distorted tetrahedral complex. The DFT study showed that Zn(II) has a distorted tetrahedral geometry. The lower values of the energy gap, $E_{\mathrm{g}}$, for the complexes indicated that the complexes are more reactive than the free ligand. Among the prepared complexes, $\mathrm{Cu}$ (II) showed the highest softness and electrophilicity, which could indicate favourable biological activity. Moreover, kinetic data collected from the thermal study showed highstability compounds by increasing the $E_{\mathrm{a}}$ value with an endothermic reaction $(\Delta G>0)$ through the decomposition process.

The binding constant $\left(K_{\mathrm{b}}\right)$ and Gibbs free energy $(\Delta G)$ values from the DNA-binding study for the metal complexes and the free ligand revealed an intercalation binding mode with high unprompted binding. The addition of the $\mathrm{Cu}-\mathrm{TM}$ compound resulted in hyperchromism in the HSA absorption peak, while Zn-TM showed hypochromism and practical binding to the HSA protein, $9.87 \times 10^{5} \mathrm{M}^{-1}$. The zinc-based and copper-based TM complexes showed good cytotoxic activity against the MCF-7 and HCT-116 cancer cell lines. The energy scores of the molecular docking study of the ligand and its zinc-based and copper-based complexes were in good agreement with the experimental results.

\section{Author contributions}

Synthesis and characterization, A. A. S; supervision and writing original draft preparation, M. A. A.; EPR analysis, A. E.; writing, review and editing; A. E. and M. J. All authors have read and agreed to the published version of the manuscript.

\section{Conflicts of interest}

The authors declare no competing financial interest.

\section{Acknowledgements}

We thank King Fahad Medical Research Center for the use of their facilities and also thank King Abdullah University of Science and Technology (KAUST) for their financial support. The simulations in this work were performed at King Abdulaziz University's High-Performance Computing Center (Aziz Supercomputer) (http://hpc.kau.edu.sa).

\section{References}

1 S. Rafique, M. Idrees, A. Nasim, H. Akbar and A. Athar, Transition metal complexes as potential therapeutic agents, Biotechnol. Mol. Biol. Rev., 2010, 5(2), 38-45.

2 L.-F. Li, H. Wang, J. Zhang, C. Ma, Y.-Y. Li, L. Wang, S.-K. Liang, H.-T. Jin, S.-J. Liu and M.-C. Zhu, Syntheses, characterization, interaction with DNA, cytotoxic and apoptosis of two novel complexes of $\mathrm{Zn}$ (II) and Mn(II) with 2-methyl-1H-4,5-imidazoledicarboxylic acid, Eur. J. Med. Chem., 2015, 92, 295-301.

3 R. M. Roat-Malone, Bioinorganic chemistry: a short course, John Wiley \& Sons, 2007.

4 F. Tisato, C. Marzano, M. Porchia, M. Pellei and C. Santini, Copper in diseases and treatments, and copper-based anticancer strategies, Med. Res. Rev., 2010, 30(4), 708-749.

5 H. Sahyon, A. El-Bindary, A. Shoair and A. Abdellatif, Synthesis and characterization of ruthenium(III) complex containing 2-aminomethyl benzimidazole, and its anticancer activity of in vitro and in vivo models, J. Mol. Liq., 2018, 255, 122-134.

6 H. C. Neu and K. P. Fu, In vitro activity of chloramphenicol and thiamphenicol analogs, Antimicrob. Agents Chemother., 1980, 18(2), 311-316.

7 G. Indrayanto, D. L. Trisna, M. H. Santosa, R. Handajani, T. Agustono and P. Sucipto, Thiamphenicol, Analytical Profiles of Drug Substances and Excipients, Elsevier, 1993, vol. 22, pp. 461-488.

8 O. A. El-Gammal, F. S. Mohamed, G. N. Rezk and A. A. ElBindary, Synthesis, characterization, catalytic, DNA binding and antibacterial activities of $\mathrm{Co}(\mathrm{II}), \mathrm{Ni}(\mathrm{II})$ and $\mathrm{Cu}(\mathrm{II})$ complexes with new Schiff base ligand, J. Mol. Liq., 2021, 326, 115223.

9 M. Frisch, G. Trucks, H. B. Schlegel, G. E. Scuseria, M. A. Robb, J. R. Cheeseman, G. Scalmani, V. Barone, B. Mennucci and G. Petersson, Gaussian 09, Revision D. 01, Gaussian Inc., Wallingford CT, 2009, p. 201.

10 N. I. o. Standards, Technology, Precomputed Vibrational Scaling Factors, 2018.

11 R. Dennington, T. Keith and J. Millam, GaussView, Version 4.1.2. Semichem Inc., Shawnee Mission, KS 2007.

12 A. A. Sharfalddina, A.-H. Emwasb, M. Jaremkoc and M. A. Hussien, Transition Metal Complexes of 6Mercaptopurine; Characterization, DFT Calculation, DNA binding, Molecular Docking, and Anticancer Activity, Appl. Organomet. Chem., 2020, 35(1), e6041. 
13 A. Sharfalddin, B. Davaasuren, A.-H. Emwas, M. Jaremko, Ł. Jaremko and M. Hussien, Single crystal, Hirshfeld surface and theoretical analysis of methyl 4-hydroxybenzoate, a common cosmetic, drug and food preservative---Experiment versus theory, PLoS One, 2020, 15(10), e0239200.

14 A. A. Sharfalddin, A.-H. M. Emwas, M. Jaremko and M. A. Abdulala, Practical and Computational studies of Bivalence Metal Complexes of Sulfaclozine and Biological Studies, Front. Chem., 2021, in press.

15 L. H. Abdel-Rahman, A. M. Abu-Dief and A. A. H. AbdelMawgoud, Development, structural investigation, DNA binding, antimicrobial screening and anticancer activities of two novel quari-dentate $\mathrm{VO}(\mathrm{II})$ and $\mathrm{Mn}$ (II) mononuclear complexes, J. King Saud Univ., Sci., 2019, 31(1), 52-60.

16 A. Wolfe, G. H. Shimer Jr and T. Meehan, Polycyclic aromatic hydrocarbons physically intercalate into duplex regions of denatured DNA, Biochemistry, 1987, 26(20), 6392-6396.

17 L. H. Abdel-Rahman, M. S. S. Adam, A. M. Abu-Dief, H. Moustafa, M. T. Basha, A. S. Aboraia, B. S. Al-Farhan and H. E. S. Ahmed, Synthesis, theoretical investigations, biocidal screening, DNA binding, in vitro cytotoxicity and molecular docking of novel $\mathrm{Cu}$ (II), $\mathrm{Pd}$ (II) and $\mathrm{Ag}$ (I) complexes of chlorobenzylidene Schiff base: Promising antibiotic and anticancer agents, Appl. Organomet. Chem., 2018, 32(12), e4527.

18 D. Sabolová, M. Kožurková, T. Plichta, Z. Ondrušová, D. Hudecová, M. Šimkovič, H. Paulíková and A. Valent, Interaction of a copper(II)-Schiff base complexes with calf thymus DNA and their antimicrobial activity, Int. J. Biol. Macromol., 2011, 48(2), 319-325.

19 M. Mokhtar, T. S. Saleh, N. S. Ahmed and A. S. Al-Bogami, A Green Mechanochemical One-Pot Three-Component Domino Reaction Synthesis of Polysubstituted Azoloazines Containing Benzofuran Moiety: Cytotoxic Activity Against HePG2 Cell Lines, Polycyclic Aromat. Compd., 2018, 1-15.

20 G. A. Fawzy, H. Y. Al Ati and A. A. El Gamal, Chemical composition and biological evaluation of essential oils of Pulicaria jaubertii, Pharmacogn. Mag., 2013, 9(33), 28.

21 I. Ali, W. A. Wani and K. Saleem, Empirical formulae to molecular structures of metal complexes by molar conductance, Synth. React. Inorg., Met.-Org., Nano-Met. Chem., 2013, 43(9), 1162-1170.

22 G. Fazakerley, P. W. Linder and L. Nassimbeni, Complexation of copper(II) by chloramphenicol, Inorg. Nucl. Chem. Lett., 1973, 9(10), 1069-1072.

23 L. H. Abdel-Rahman, A. M. Abu-Dief, H. Moustafa and S. K. Hamdan, $\mathrm{Ni}(\mathrm{II})$ and $\mathrm{Cu}(\mathrm{II})$ complexes with ONNO asymmetric tetradentate Schiff base ligand: synthesis, spectroscopic characterization, theoretical calculations, DNA interaction and antimicrobial studies, Appl. Organomet. Chem., 2017, 31(2), e3555.

24 L. H. Abdel-Rahman, A. M. Abu-Dief, R. M. El-Khatib and S. M. Abdel-Fatah, Some new nano-sized Fe(II), Cd(II) and $\mathrm{Zn}$ (II) Schiff base complexes as precursor for metal oxides: Sonochemical synthesis, characterization, DNA interaction, in vitro antimicrobial and anticancer activities, Bioorg. Chem., 2016, 69, 140-152.
25 R. J. Alvarez-Mendez, S. Escalante, J. M. Fernández-G, S. Hernández-Ortega, R. Salcedo and A. Vela, The squareplanar structure of bis [N-(i-propyl)-3-oxy-2-naphthaldiminato] copper(II), J. Coord. Chem., 2014, 67(14), 2405-2414.

$26 \mathrm{~J}$. K. Burdett, A New Look at Structure and Bonding in Transition Metal Complexes, in Advances in Inorganic Chemistry and Radiochemistry, Academic Press, 1978, vol. 21, pp. 113-146.

27 A. Mohammad, C. Varshney and S. A. Nami, Synthesis, characterization and antifungal activities of 3d-transition metal complexes of 1-acetylpiperazinyldithioc arbamate, M (acpdtc) 2, Spectrochim. Acta, Part A, 2009, 73(1), 20-24.

28 E. J. Hawrelak, W. H. Bernskoetter, E. Lobkovsky, G. T. Yee, E. Bill and P. J. Chirik, Square planar vs tetrahedral geometry in four coordinate iron(II) complexes, Inorg. Chem., 2005, 44(9), 3103-3111.

29 D. Forster and D. Goodgame, Preparation and electronic spectra of some tetrahedral complexes of iron(II), J. Chem. Soc., 1965, 454-458.

30 P. Gütlich, J. Jung and H. A. Goodwin, Spin transitions in Iron(II) complexes, in Molecular Magnetism: from molecular assemblies to the devices, Springer, 1996, pp. 327-378.

31 A. M. Abu-Dief and L. A. Nassr, Tailoring, physicochemical characterization, antibacterial and DNA binding mode studies of $\mathrm{Cu}$ (II) Schiff bases amino acid bioactive agents incorporating 5-bromo-2-hydroxybenzaldehyde, J. Iran. Chem. Soc., 2015, 12(6), 943-955.

32 M. A. Haque, A. N. Gandi, R. Mohanraman, Y. K. Weng, B. Davaasuren, A. H. Emwas, C. Combe, D. Baran, A. Rothenberger, U. Schwingenschlogl, H. N. Alshareef, S. Dong and T. Wu, A OD Lead-Free Hybrid Crystal with Ultralow Thermal Conductivity, Adv. Funct. Mater., 2019, 29, 13.

33 I. M. Kooter, R. A. Steiner, B. W. Dijkstra, P. I. van Noort, M. R. Egmond and M. Huber, EPR characterization of the mononuclear Cu-containing Aspergillus japonicus quercetin 2,3-dioxygenase reveals dramatic changes upon anaerobic binding of substrates, Eur. J. Biochem., 2002, 269(12), 2971-2979.

34 S. M. Mattar, A. H. Emwas and L. A. Calhoun, Spectroscopic studies of the intermediates in the conversion of 1,4,11,12tetrahydro-9,10-anthraquinone to 9,10-anthraquinone by reaction with oxygen under basic conditions, J. Phys. Chem. A, 2004, 108(52), 11545-11553.

35 J. Al-Nu'airat, B. Z. Dlugogorski, I. Oluwoye, X. P. Gao and M. Altarawneh, Effect of $\mathrm{Fe}_{2} \mathrm{O}_{3}$ nanoparticles on combustion of coal surrogate (Anisole): Enhanced ignition and formation of persistent free radicals, Proc. Combust. Inst., 2019, 37(3), 3091-3099.

36 G. D. Fang, X. R. Chen, W. H. Wu, C. Liu, D. D. Dionysiou, T. T. Fan, Y. J. Wang, C. Y. Zhu and D. M. Zhou, Mechanisms of Interaction between Persulfate and Soil Constituents: Activation, Free Radical Formation, Conversion, and Identification, Environ. Sci. Technol., 2018, 52(24), 14352-14361. 
37 S. M. Mattar, A. D. Stephens and A. H. Emwas, Generation and spectroscopic characterization of the 2,3,5,6tetramethoxy-1,4-benzosemiquinone reactive intermediate, Chem. Phys. Lett., 2002, 352(1-2), 39-47.

38 A. I. Poddel'sky, V. K. Cherkasov and G. A. Abakumov, Transition metal complexes with bulky 4,6-di-tert-butyl- $N$ aryl(alkyl)-o-iminobenzoquinonato ligands: Structure, EPR and magnetism, Coord. Chem. Rev., 2009, 253(3-4), 291-324.

39 S. Vancoillie, P. A. Malmqvist and K. Pierloot, Calculation of EPR $g$ tensors for transition-metal complexes based on multiconfigurational perturbation theory (CASPT2), ChemPhysChem, 2007, 8(12), 1803-1815.

40 W. L. Zhang, Z. Cao, W. X. Wang, E. Alhajji, A. H. Emwas, P. Costa, L. Cavallo and H. N. Alshareef, A Site-Selective Doping Strategy of Carbon Anodes with Remarkable K-Ion Storage Capacity, Angew. Chem., Int. Ed., 2020, 59(11), 4448-4455.

41 Y.-M. Lee, B.-J. Kim, H.-J. Kim, S.-Y. Kim, S. K. Kang and S.N. Choi, Crystal structures and spectroscopic properties of copper(II) pseudohalide complexes with two sparteine epimers, having a $\mathrm{CuN}_{4}$ chromophore, Polyhedron, 2009, 28(14), 3060-3064.

42 L. Li, X. Shi, C. M. Evans and G. L. Findley, Atomic and Molecular Low-n Rydberg States in Near Critical Point Fluids, Adv. Aspects Spectrosc., 2012, 451.

43 E. Garribba and G. Micera, The determination of the geometry of $\mathrm{Cu}$ (II) complexes: an EPR spectroscopy experiment, J. Chem. Educ., 2006, 83(8), 1229.

44 M. M. Ibrahim, A.-M. M. Ramadan, H. S. El-Sheshtawy, M. A. Mohamed, M. Soliman and S. IM Zayed, Synthesis, characterization and medical efficacy (hepatoprotective and antioxidative) of albendazole-based copper(II) complexes-an experimental and theoretical approach, J. Coord. Chem., 2015, 68(24), 4296-4313.

45 R. Mogili, M. Ravinder, K. Mamatha, N. Padmaja and S. Srihari, Synthesis, Characterization and Antimicrobial Activity of some Quinoxaline derivatives and their Metal Complexes, J. Pharm. Chem., 2007, 1, 35-39.

46 D. Kivelson and R. Neiman, ESR studies on the bonding in copper complexes, J. Chem. Phys., 1961, 35(1), 149-155.

47 A. Shoair, A. El-Bindary, N. El-Ghamaz and G. Rezk, Synthesis, characterization, DNA binding and antitumor activities of $\mathrm{Cu}(\mathrm{II})$ complexes, J. Mol. Liq., 2018, 269, 619-638.

48 B. Hathaway and D. Billing, The electronic properties and stereochemistry of mono-nuclear complexes of the copper(II) ion, Coord. Chem. Rev., 1970, 5(2), 143-207.

49 A. Coats and J. Redfern, Thermogravimetric analysis. A review, Analyst, 1963, 88(1053), 906-924.

50 A. Siddalingaiah and S. G. Naik, Spectroscopic and thermogravimetric studies on $\mathrm{Ni}(\mathrm{II}), \mathrm{Cu}(\mathrm{II})$ and $\mathrm{Zn}$ (II) complexes of di (2,6-dichlorophenyl) carbazone, THEOCHEM, 2002, 582(1-3), 129-136.

51 A. Frost and R. Pearson, Kinetics and mechanism, J. Phys. Chem., 1961, 65(2), 384.

52 A. El-Bindary, S. El-Marsafy and A. El-Maddah, Enhancement of the photocatalytic activity of $\mathrm{ZnO}$ nanoparticles by silver doping for the degradation of AY99 contaminants, J. Mol. Struct., 2019, 1191, 76-84.

53 H. Kiwaan, T. Atwee, E. Azab and A. El-Bindary, Photocatalytic degradation of organic dyes in the presence of nanostructured titanium dioxide, J. Mol. Struct., 2020, 1200, 127115.

54 A. El-Sonbati, M. Diab, A. El-Bindary, M. Abou-Dobara and H. Seyam, Molecular docking, DNA binding, thermal studies and antimicrobial activities of Schiff base complexes, J. Mol. Liq., 2016, 218, 434-456.

55 N. S. Abdel-Kader, S. A. Abdel-Latif, A. L. El-Ansary and A. G. Sayed, Combined experimental, DFT theoretical calculations and biological activity of sulfaclozine azo dye with 1hydroxy-2-naphthoic acid and its complexes with some metal ions, New J. Chem., 2019, 43(44), 17466-17485.

56 L. H. Abdel-Rahman, A. M. Abu-Dief, M. Ismael, M. A. Mohamed and N. A. Hashem, Synthesis, structure elucidation, biological screening, molecular modeling and DNA binding of some $\mathrm{Cu}(\mathrm{II})$ chelates incorporating imines derived from amino acids, J. Mol. Struct., 2016, 1103, 232-244.

57 A. A. Sharfalddin and M. A. Hussien, Bivalence Metal Complexes of Antithyroid Drug Carbimazole; Synthesis, Characterization, Computational simulation, and Biological Studies, J. Mol. Struct., 2020, 129725.

58 R. Parthasarathi, V. Subramanian, D. R. Roy and P. Chattaraj, Electrophilicity index as a possible descriptor of biological activity, Bioorg. Med. Chem., 2004, 12(21), 5533-5543.

59 M. Sirajuddin, S. Ali and A. Badshah, Drug-DNA interactions and their study by UV-Visible, fluorescence spectroscopies and cyclic voltametry, J. Photochem. Photobiol., B, 2013, 124, 1-19.

60 F. Arjmand and A. Jamsheera, DNA binding studies of new valine derived chiral complexes of tin(Iv) and zirconium(Iv), Spectrochim. Acta, Part A, 2011, 78(1), 45-51.

61 N. Shahabadi, S. Kashanian, M. Khosravi and M. Mahdavi, Multispectroscopic DNA interaction studies of a watersoluble nickel(II) complex containing different dinitrogen aromatic ligands, Transition Met. Chem., 2010, 35(6), 699-705.

62 K. Ashwini Kumar, K. L. Reddy, S. Vidhisha and S. Satyanarayana, Synthesis, characterization and DNA binding and photocleavage studies of $[\mathrm{Ru}(\mathrm{bpy}) 2 \mathrm{BDPPZ}]^{2+}$, $[\mathrm{Ru}(\mathrm{dmb}) 2 \mathrm{BDPPZ}]^{2+}$ and [Ru(phen)2BDPPZ $]^{2+}$ complexes and their antimicrobial activity, Appl. Organomet. Chem., 2009, 23(10), 409-420.

63 A. M. Abu-Dief, L. H. Abdel-Rahman and A. A. H. AbdelMawgoud, A robust in vitro anticancer, antioxidant and antimicrobial agents based on new metal-azomethine chelates incorporating $\mathrm{Ag}$ (I), $\mathrm{Pd}(\mathrm{II})$ and $\mathrm{VO}(\mathrm{II})$ cations: Probing the aspects of DNA interaction, Appl. Organomet. Chem., 2020, 34(2), e5373.

64 S. Tabassum, M. Zaki, M. Ahmad, M. Afzal, S. Srivastav, S. Srikrishna and F. Arjmand, Synthesis and crystal structure determination of copper(II)-complex: in vitro 
DNA and HSA binding, pBR322 plasmid cleavage, cell imaging and cytotoxic studies, Eur. J. Med. Chem., 2014, 83, 141-154.

65 S. Al-Harthi, J. I. Lachowicz, M. E. Nowakowski, M. Jaremko and $\mathrm{\iota}$. Jaremko, Towards the functional high-resolution coordination chemistry of blood plasma human serum albumin, J. Inorg. Biochem., 2019, 198, 110716.

66 A. J. Stewart, C. A. Blindauer, S. Berezenko, D. Sleep, D. Tooth and P. J. Sadler, Role of Tyr84 in controlling the reactivity of Cys34 of human albumin, FEBS J., 2005, 272(2), 353-362.

67 M. H. Baig, S. Rahman, G. Rabbani, M. Imran, K. Ahmad and I. Choi, Multi-spectroscopic characterization of human serum albumin binding with cyclobenzaprine hydrochloride: insights from biophysical and in silico approaches, Int. J. Mol. Sci., 2019, 20(3), 662.
68 B. Tweedy, Plant extracts with metal ions as potential antimicrobial agents, Phytopathology, 1964, 55, 910-914.

69 A. A. Al-Amiery, A. A. H. Kadhum and A. B. Mohamad, Antifungal and antioxidant activities of pyrrolidone thiosemicarbazone complexes, Bioinorg. Chem. Appl., 2012, 2012, 795812.

70 K. S. Prasad, L. S. Kumar, S. C. Shekar, M. Prasad and H. Revanasiddappa, Oxovanadium complexes with bidentate N, O ligands: synthesis, characterization, DNA binding, nuclease activity and antimicrobial studies, Chem. Sci. J., 2011, 12, 1-10.

71 L. H. Abdel-Rahman, A. M. Abu-Dief, M. O. Aboelez and A. A. H. Abdel-Mawgoud, DNA interaction, antimicrobial, anticancer activities and molecular docking study of some new $\mathrm{VO}(\mathrm{II}), \mathrm{Cr}(\mathrm{III}), \mathrm{Mn}$ (II) and $\mathrm{Ni}(\mathrm{II})$ mononuclear chelates encompassing quaridentate imine ligand, J. Photochem. Photobiol., B, 2017, 170, 271-285. 